\title{
Protected cultivation of vegetable crops in sub-Saharan Africa: limits and prospects for smallholders. A review
}

\author{
Thibault Nordey ${ }^{1,2}$. Claudine Basset-Mens ${ }^{1,3} \cdot$ Hubert De Bon ${ }^{1}$ - Thibaud Martin ${ }^{1,4}$. \\ Emilie Déletré $^{1,4}$ - Serge Simon ${ }^{1,5}$ • Laurent Parrot ${ }^{1}$ - Hugo Despretz ${ }^{2}$ - Joël Huat ${ }^{1,6}$. \\ Yannick Biard $^{1} \cdot$ Thomas Dubois $^{2} \cdot$ Eric Malézieux $^{1}$
}

Accepted: 11 September 2017 / Published online: 18 October 2017

(C) INRA and Springer-Verlag France SAS 2017

\begin{abstract}
Vegetable production in sub-Saharan Africa faces numerous agronomic constraints that will have to be overcome to feed the increasing population and to fight malnutrition. Technology transfer and the adoption of low-tech protected cultivation techniques affordable for smallholders are believed to be able to meet this challenge. Protected cultivation techniques are a set of agricultural practices aimed at artificializing the crop environment through the use of soil covers and/or plant covers to control pests and climatic conditions. Although protected cultivation techniques may increase the yield and quality of vegetable crops and extend their production periods worldwide, the transfer of these techniques in sub-Saharan Africa raises questions about their agronomical performances, their profitability but also their environmental impacts. Are low-tech protected cultivation techniques adapted to the sustainable production of vegetables by smallholders in sub-Saharan Africa? To answer this question, we present an overview of the agronomic, economic, and environmental performances of low-tech protected cultivation techniques in sub-Saharan Africa as reported in the literature. The major conclusions that can be drawn from the review are
\end{abstract}

Thibault Nordey

thibault.nordey@cirad.fr

1 CIRAD, UPR Hortsys, 34398 Montpellier, France

2 The World Vegetable Center, Eastern and Southern Africa, P.O. Box 10, Duluti, Arusha, Tanzania

3 Campus Agro-environnemental Caraïbe, Petit Morne BP 214, 97285 Le Lamentin Cedex 2, Martinique, France

4 ICIPE, Department Plant Health, Kasarani, Nairobi 00100, Kenya

5 ISRA, Bel-Air BP, 3120 Dakar, Senegal

6 CIRAD, BP 1304 Kaweni, 97600 Mamoudzou, Mayotte, France
(1) low-tech protected cultivation techniques are not suitable in all climatic conditions in sub-Saharan Africa and need to be combined with other methods to ensure adequate pest control, (2) the profitability of protected cultivation techniques relies on the capacity to offset increased production costs by higher yields and higher selling prices to be obtained with off-season and/or higher quality products, (3) breaking with existing cropping systems, the lack of technical support and skills, and the limited access to investment funding are major obstacles to the adoption of protected cultivation techniques by smallholders (4) life cycle assessments conducted in northern countries suggested that more efficient use of agricultural inputs would offset the negative impacts of protected cultivation techniques if they are properly managed, but further studies are required to be sure these results can be extrapolated to subSaharan Africa context.

Keywords Greenhouse · Tunnel · Netting · Profitability · Insect pests $\cdot$ Quality $\cdot$ Life cycle assessment

\section{Contents}

1. Introduction

1.1 Suitability of protected cultivation for vegetable cropping systems in sub-Saharan Africa

1.1.1 Climatic suitability of protected cultivation in sub-Saharan Africa

1.1.2 Control of insect pests with protected cultivation

1.1.3 Changes in cropping systems induced by protected cultivation techniques

1.2 Suitability of protected cultivation techniques for the socio-economic context of smallholders

1.2.1 Improvements in crop production with protected cultivations techniques

1.2.2 Profitability of protected cultivation 
1.2.3 Brakes on the adoption of protected cultivation techniques by smallholders

1.3 Environmental impacts of protected cultivation

2. Conclusion

References

\section{Introduction}

In the last decade, world vegetable production underwent a remarkable increase from 0.69 billion metric tons in 2003 to 1.72 billion metric tons in 2013 (FAO 2013). Nevertheless, large yield gaps still exist worldwide and many countries still do not produce enough fruit and vegetables to satisfy the micronutrient needs of their population, particularly in subSaharan Africa (SSA). The forecasted 9.1 billion world population in 2050 will require a $60 \%$ increase in agricultural and horticultural production and is a major concern since the structural change in diet in favor of fruits and vegetables observed in recent decades is expected to continue (Alexandratos and Bruinsma 2012). Urban areas of developing countries where most of population growth is expected to take place are particularly concerned by this challenge (FAO 2009). The main vegetable products in Africa in 2013 were tomatoes (19.1 MT), onions (10.8), watermelons (6.4 MT), cabbages and other brassica (4.1 MT), of dates in 2013 (FAO 2013). However, few data are available concerning the production of African leafy vegetables. Although yields of open field tomatoes (Lycopersicon esculentum Mill.) usually range between 40 and $100 \mathrm{t} \mathrm{ha}^{-1}$ (Heuvelink 2005) depending on agro climatic conditions and cultural practices, it is estimated that, with the exception of South Africa, the average tomato yield in SSA countries is less than $19.4 \mathrm{t} \mathrm{ha}^{-1}$ (FAO 2013).

Vegetable production faces several problems, biotic problems including insect pests, diseases and weeds, and abiotic problems such as drought, floods, and low soil fertility. As a result, vegetable production depends to a great extent on climatic conditions leading to marked seasonal variations in supply. The high added economic value of vegetable production, the high labor requirements, and the small cultivated area have favored the artificialization of vegetable cropping systems to reduce the impacts of biotic and abiotic limiting factors and thereby stabilize the level of production. The desire to control the environment of vegetable crops has a long history: Roman agricultural writers reported that the Emperor Tiberius (42 BC-37 AC) could enjoy fresh snake melons (Cucumis melo subsp. Melo Flexuosus) during the cold season by using covers made of transparent stones, i.e., lapis specularis or mica (Paris and Janick 2008). From this time on, the use of glass to protect horticultural crops from cold temperatures has been reported in Europe and Japan as well as to produce out of season fruits, vegetables, and flowers (Ponce et al. 2014; Jensen and Malter 1995). Nevertheless, it was only in the 1950s that protected cultivation attracted widespread interest with the introduction of polyethylene in agriculture applications. This marked the start of massive use of plastic in agriculture worldwide particularly under temperate climates, called plasticulture, which was preferred to glass because of its lower cost, lower weight, and greater versatility. The current estimated annual consumption of plastic for agriculture worldwide is 6.5 million tons (Scarascia-Mugnozza et al. 2012). Numerous plastic polymers are used in agriculture, including polyethylene, polypropylene, polyvinylchloride, ethylenvinylacetate, polymethylmethacrylate and polycarbonate. These plastic polymers are used to manufacture different materials including covers, framework, pipes and tanks. The use of plastic for vegetable production is increasing all over the world but differs considerably in the degree of sophistication of the methods used, thereby testifying to marked differences in the agronomic and socio-economic contexts.

The term 'protected agriculture' covers different protected cultivation techniques (PCT) used with the same objective, to modify the natural environment to achieve optimal plant growth. The first distinction is the height of the PCT device, which distinguishes three groups: mulch, row covers, and high shelters. Mulch is used to cover the soil with an organic or a synthetic material to increase the temperature of the soil and maintain soil moisture, and to reduce soil compaction, weed development, nutrient leaching, and to prevent insect pests doing their pupal stage in the soil (Fig. 1a, b). The area of the soil covered by low tunnel is generally limited to the bed row (row cover, Fig. 1c, d), while high shelters (or high tunnel, Fig. 1d to f) cover the whole soil area and plant system with translucent materials to improve the climatic conditions and to protect the crop from insect pests, birds, and excessive wind, rain or solar radiation. The term 'high shelter' covers different forms that are more and less confined, ranging from covers simply placed above the crop to protect it from excessive solar radiation (shade nets, Fig. 1e) or rain (rain shelter), open high tunnels to greenhouses (Fig. 1e, f). Greenhouses exist in many forms in terms of glazing, framework materials, design and the level of technology used to control the plant environment to suit the agronomic and socio-economic context. The level of technology used to control the plant environment is an important feature that distinguishes three main groups of greenhouses, i.e., low, medium and high technology (Ponce et al. 2014). Low technology refers to systems in which the plant environment is poorly controlled, i.e. substrate cultivation without heating or cooling systems. Low-tech PCT extends period of production and enables the production of early season vegetables. Medium technology refers to structures with "semi-climate control," which use simple systems to control temperature and irrigation or hydroponic systems. Such systems may make it possible to produce vegetables all year round. High tech systems, also called controlled environment agriculture, refer to a system of environmental control that 
Fig. 1 Diversity of protected cultivation techniques in SSA, plastic mulch on okras in Tanzania (a), organic mulch on African eggplants in Burundi (b), low insect proof nets tunnels on cabbages in Benin (c), shade nets on tomatoes in Senegal (d), tomato cultivation in a nethouse in Kenya (e) and cultivation of sweet peppers in a polyhouse in Tanzania (f)
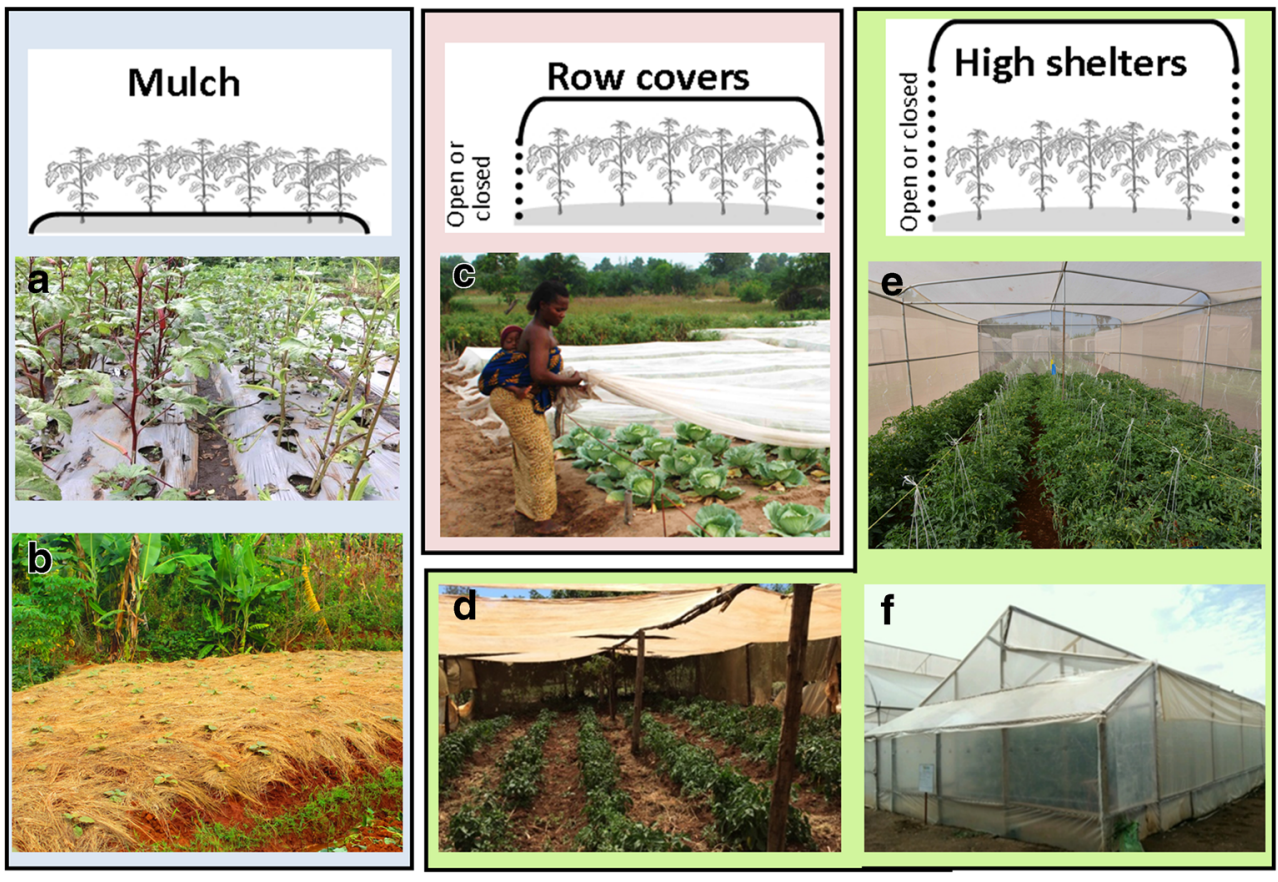

allows regulation of air and root temperature, air moisture, water and nutriment supply, light and atmospheric gas composition. Such systems are used to produce vegetables all year round with the highest yield (Ponce et al. 2014; Jensen and Malter 1995).

Statistics on the extent of areas dedicated to protected agriculture are difficult to obtain given the different forms and adaptations of PCT. Nevertheless, it is estimated that the total area under greenhouses worldwide is between 400,000 and 500,000 ha (Chang et al. 2013; Baudoin et al. 2013) in comparison with an estimated 221,000 ha in 1989 (Jensen and Malter 1995). Row covers are estimated to account for a comparable area whereas the area covered by plastic mulch is estimated to be three time higher (Ponce et al. 2014). No statistics are available, but it can be assumed that the area covered by mulch — including organic mulches - is much higher since it is a common practice in vegetable production in places where sufficient biomass is available.

Nowadays, with properly designed high technology systems, it appears to be possible to cultivate any horticultural species in any region of the world, allowing crops to be cultivated that are totally disconnected from the real climate conditions (Castilla 2013; Baudoin et al. 2013). This is the case in the Netherlands where tomato yields can exceed 550 metric tons $\mathrm{ha}^{-1}$ year ${ }^{-1}$, making the Netherlands the world leader in intensification of fresh tomato production (Heuvelink 2005).

Protected cultivation methods are adopted worldwide with varying rates and degrees of success. Today, China accounts for most of the area dedicated to the cultivation of vegetables in plastic greenhouses (Chang et al. 2013; Ponce et al. 2014; Hu et al. 2017) whereas the African continent accounts for less than $5 \%$ of area dedicated to protected agriculture in the world (Ponce et al. 2014). In Africa, smallholder farmers, i.e., producers whose farms are two hectares or less in size, represent $80 \%$ of all farmers (Wiggins 2009). A typology with 3 to 5 categories is often used to characterize the marked differences in resources endowment between smallholder farms and to explain differences in access to inputs, dependence on nonfarm incomes, management of the cropping system and production objectives (Chikowo et al. 2014). There is wide consensus that smallholders could play a crucial role in the reduction of poverty and malnutrition (Walpole et al. 2013; Altieri et al. 2012), although it is argued that the contribution of larger famers should not be neglected, from their involvement in the promotion of new technologies to improved marketing (Collier and Dercon 2014).

Vegetable production in SSA is seriously affected by pests and this onslaught will increase with the emergence of new insect pests such as the fruit fly Bactrocera spp., the red spider mite Tetranychus evansi (Azandémè-Hounmalon et al. 2015) and recently the tomato leaf miner Tuta absoluta in SSA, which has caused up to $100 \%$ yield losses in some regions (Brévault et al. 2014; Tonnang et al. 2015; Chidege et al. 2016). In Africa, pest control mainly relies on the use of chemical pesticides but this approach is not sustainable due to the development of resistance (Martin et al. 2002; Carletto et al. 2010; Houndété et al. 2010; Agboyi et al. 2016) as well as their impacts on the environment and on human health (Wilson and Tisdell 2001; De Bon et al. 2014). Alarming studies in Ghana (Bempah et al. 2012; Bempah et al. 2016), Benin (Yehouenou et al., 2013), Senegal (Diop et al. 2016) and in South Africa (Mutengwe et al. 2016) highlight the risks 
involved in consuming vegetables due to pesticide residues above the approved maximum residues levels (MLR).

For several years, several research works and projects have been dedicated to the development of low-tech PCT affordable for smallholders to overcome agronomic constraints in SSA (Parrot et al. 2014). Research has focused on the reduction of pest pressure, including insects, birds and weeds and on the mitigation of climatic hazards including excessive solar irradiation, rain and wind, using physical protection (Fig. 1). The physical protection against crop pests provided by PCT has been considered as a very promising solution to increase the yield and quality of vegetable production in SSA while reducing the use of chemical treatments (Weintraub 2009; Martin 2015). However, the results of protected cultivation in SSA have been reported to be contrasted because of temperature and insects pest issues as well as limitations to the adoption of PCT by smallholders. The increased use of plastic in vegetable cropping systems with PCT also raises environmental concerns that cannot be ignored given the low biodegradability of these materials and their impact on terrestrial and marine ecosystems (Jambeck et al. 2015; Sharma and Bansal 2016).

The aim of the present work was to evaluate the interest of low tech protected cultivation techniques for small vegetable growers in SSA using a global approach and including agronomic, economic and environmental aspects. The first part of this review focuses on the capacity and suitability of protected cultivation techniques to improve the performances of vegetable cropping systems in SSA while accounting for climatic, insect pests and agronomic issues. The second part is dedicated to the ability of protected cultivation techniques to meet the socio-economic needs and objectives of smallholders by considering the profitability and the limits of adoption. In the third part, the environmental impacts of protected cultivation are discussed.

\subsection{Suitability of protected cultivation for vegetable cropping systems in sub-Saharan Africa}

Protected cultivation takes various forms around the world depending on agronomic issues and socio-economic contexts. As suggested above, one of the main distinguishing factors of PCTs is the level of technology used to control the plant environment. Modern technologies make it possible to fully control both the physical and biological crop environment (plant, soil, atmosphere, and pests) to obtain yields close to the biological potential, even in climates that provide far from optimal conditions for crops. Nevertheless, the use of high-tech PCT requires significant (if not huge) investments and energy inputs that may be far from the economic optimum especially for smallholders. This may explain why low tech systems are more frequently preferred by smallholders in many conditions, especially in SSA where most crops are rain fed (Burney et al. 2013). Low-tech PCT enable much less control of the plant environment but may help control the most important limiting factors. In this case, vegetable production remains highly dependent on climatic conditions, which, in certain conditions, may even have a detrimental effect on crop growth and development because of excessive temperature and humidity and/or increased pest pressure. First we focus on the suitability of low tech PCT used under various climatic conditions in SSA, and then discuss the main agronomic problems involved in protected cultivation and their solutions.

\subsubsection{Climatic suitability of protected cultivation in sub-Saharan Africa}

Low tech PCTs are based on the simple use of covers on the soil or over the crops to limit water, gas, energy and insect transfers between the crops and external environment. Such covers mitigate the impact of climatic conditions, including heavy rainfall, high solar radiation, and strong winds as well as pest damages to crops, thereby allowing off season production of vegetables. Low tech PCTs enable only poor control over the crop climate since they do not use energy-based systems to regulate temperature and air moisture, such as fogging, fans, and heating systems. On the other hand, covers placed on the soil or over the crops may have undesirable effects by increasing the temperature and air moisture above that required for optimum crop development. This is notably the case with plastic mulches (Fig. 1a) used to reduce the development of weeds and soil water losses, but which can increase the soil temperature by up to $7^{\circ} \mathrm{C}$ (Lament 1993). To counteract the negative impact in tropical regions, it is recommended to use reflective mulches or to cover the plastic mulches with straw (Javier 1990).

In the same way, shade nets (Fig. 1d) and rain shelters are used to reduce heat stress and the impact of heavy rainfall on crops, but reducing incoming solar radiation simultaneously reduces crop photosynthetic activity and affects plant physiology. Optimum shading intensity varies with the crop and with the climatic conditions. In Mediterranean conditions, it was reported that $49 \%$ shade intensity increased tomato yields (Lycopersicon esculentum Mill.) in summer (Kittas et al. 2012). Several studies on tomato (Lycopersicon esculentum Mill.) (Tinyane et al. 2013), lettuce (Lactuca sativa L.) (Ntsoane et al. 2016), and sweet pepper (Capsicum annum L.) (Selahle et al. 2015) reported that shade nets have different impacts on vegetable quality depending on their transmissivity. Changes in the spectrum of incoming radiation are also known to affect insect behavior and the development of fungi (Kumar and Poehling 2006; Raviv and Antignus 2004) and it is argued that crop covers play a role as optical barriers against insect pests (for a review, see Antignus (2014)). Nevertheless, in the case of high pressure from aerial insect pests, closed shelters are preferred to protect crops. Because air exchanges with the external environment are reduced, combined with the 
capacity of the covering materials to retain part of long wave radiation, closed shelters have a major impact on air temperature and air moisture. Increases in temperature of up to $10^{\circ} \mathrm{C}$ have been reported inside greenhouses (Sethi 2009). While this increase in temperature and in air moisture under closed shelters is intended in cold regions, the effect can be detrimental to crop development in hot climates (Simon et al. 2014). Consequently, in hot climate areas, covering materials with high transmissivity to PAR (photosynthetically active radiation), low transmissivity to NIR (near infrared), i.e., from 760 to $2500 \mathrm{~nm}$, and high transmissivity to FIR (far infrared) are preferred (Von Zabeltitz 2011; Abdel-Ghany et al. 2012). Modeling approaches using computational dynamic fluids were developed to optimize the orientation and the geometry of greenhouses for improved natural ventilation (Boulard et al. 1999; Du Plessis et al. 2015), temperature distribution (Fatnassi et al. 2003) and light transmission (Sethi 2009). Porous materials such as insect-proof nets and perforated polyethylene films are used to improve natural ventilation but they simultaneously reduce physical protection against insect pests. The optimum mesh size to ensure sufficient ventilation and protection against insect pests must thus be used. However, in hot regions, permanent nets even with large mesh are reported to be detrimental for crop development because of temperature issues. In such cases, it has been advised to remove covers from crops during the day to avoid heat load (Simon et al. 2014) but this practice is labor consuming and increases the risk of damaging covers (Vidogbéna et al. $2015 b$ ) as well as of introducing insect pests.

Given the wide range of climates, it is not easy to judge the climatic suitability of greenhouses for vegetable cultivation in SSA (Fig. 2). To answer this question, the method proposed by Nisen et al. (1988), later used by Baudoin et al. (2013) and Gruda and Tanny (2014) has been applied. This method assumes that temperature and irradiation are the main limiting factors for greenhouse cultivation. It is consequently proposed to compare crop requirements with estimated climate conditions, i.e., temperature and irradiation, inside the greenhouse over the year. Here we focus on tomatoes (Lycopersicon esculentum Mill.), and assume that crop development is optimal for temperatures ranging from 22 to $28^{\circ} \mathrm{C}$, in line with values estimated by Boote et al. (2012) for tomato vegetative development, and requires exposure to light of $8.75 \mathrm{MJ} \mathrm{m}^{-2}$ day $^{-1}$ (Dorais 2003). Two greenhouse covers were tested, polyethylene film and insect-proof nets, assuming that they reduce incoming radiation by $20 \%$ (Saidi et al. 2013; Von Zabeltitz 2011), and increase air temperature by $4{ }^{\circ} \mathrm{C}$ (Simon et al. 2014) and $10^{\circ} \mathrm{C}$ (Nisen et al. 1988) (Sethi 2009), respectively. This method has been applied at several sites in SSA characterized by contrasted climatic conditions, including temperate climates, i.e. Addis Ababa (Ethiopia, Fig. 3A), Cape Town (South Africa, Fig. 3B), Harare (Zimbabwe, Fig. 3C) and Nairobi (Kenya, Fig. 3D), arid climates, including Dakar (Senegal,

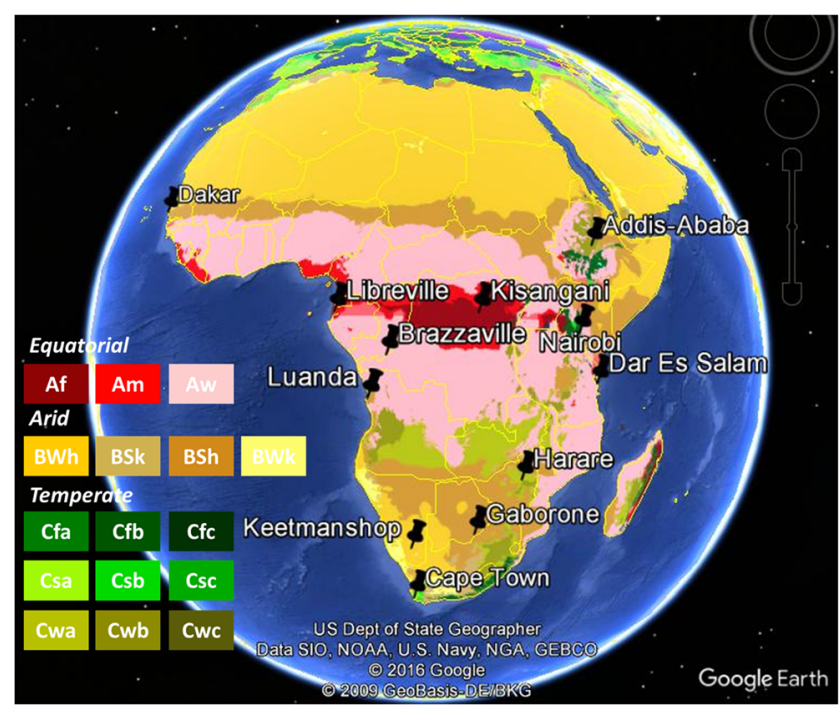

Fig. 2 Climates in Africa according to classification Köppen Geiger climate, adapted from (Kottek et al. 2006), the high-resolution map and data were uploaded from http://koeppen-geiger.vu-wien.ac.at/present. htm. Cwb, Csb, Cwa, and Cfb describe subtropical highland, warm summer Mediterranean, humid subtropical and oceanic climates, respectively, whereas $\mathrm{BSh}$ and $\mathrm{BWh}$ are related respectively to hot semi-arid and hot desert climates and Aw, Af, and Am describe tropical savanna, tropical rainforest and tropical monsoon climates, respectively

Fig. 3E), Gaborone (Bostwana, Fig. 3F), Keetmanshop (Namibia, Fig. 3G), Luanda (Angola, Fig. 3H), and equatorial climates, including Brazzaville (Republic of Congo, Fig. 3I), Dar Es Salam (Tanzania, Fig. 3J), Kisangani (Democratic Republic of Congo, Fig. 3K) and Libreville (Gabon, Fig. 3L). Meteorological data were uploaded from the website www. weatherbase.com that computes monthly average mean, maximum and minimum temperature and irradiation for periods of several years.

Figure 3 plots monthly average minimum, mean and maximum temperature versus average global radiation for each study site. The colored rectangles in Fig. 3 represent the ranges of air temperature and global radiation that match the requirements of tomato crop development in the open field and in a greenhouse covered with polyethylene film and insect proof nets.

Whatever the location considered, the radiation requirements of the tomato crops were largely satisfied even under greenhouse cultivation, except for 2 months in Cape Town.

At the study sites with temperate climatic conditions, i.e., Addis Ababa (Fig. 3A), Cape Town (Fig. 3B), Harare (Fig. 3C), and Nairobi (Fig. 3D), the increase of temperature with net covers was found to be profitable for year-round greenhouse cultivation of tomato in line with (Saidi et al. 2013). Similar results were found for polyethylene film, although higher impacts on temperature than net covers would be detrimental during the warm season in Cape Town (Fig. 3B), Harare (Fig. 3C), and Nairobi (Fig. 3D). Nevertheless, in Addis Ababa, i.e. subtropical 


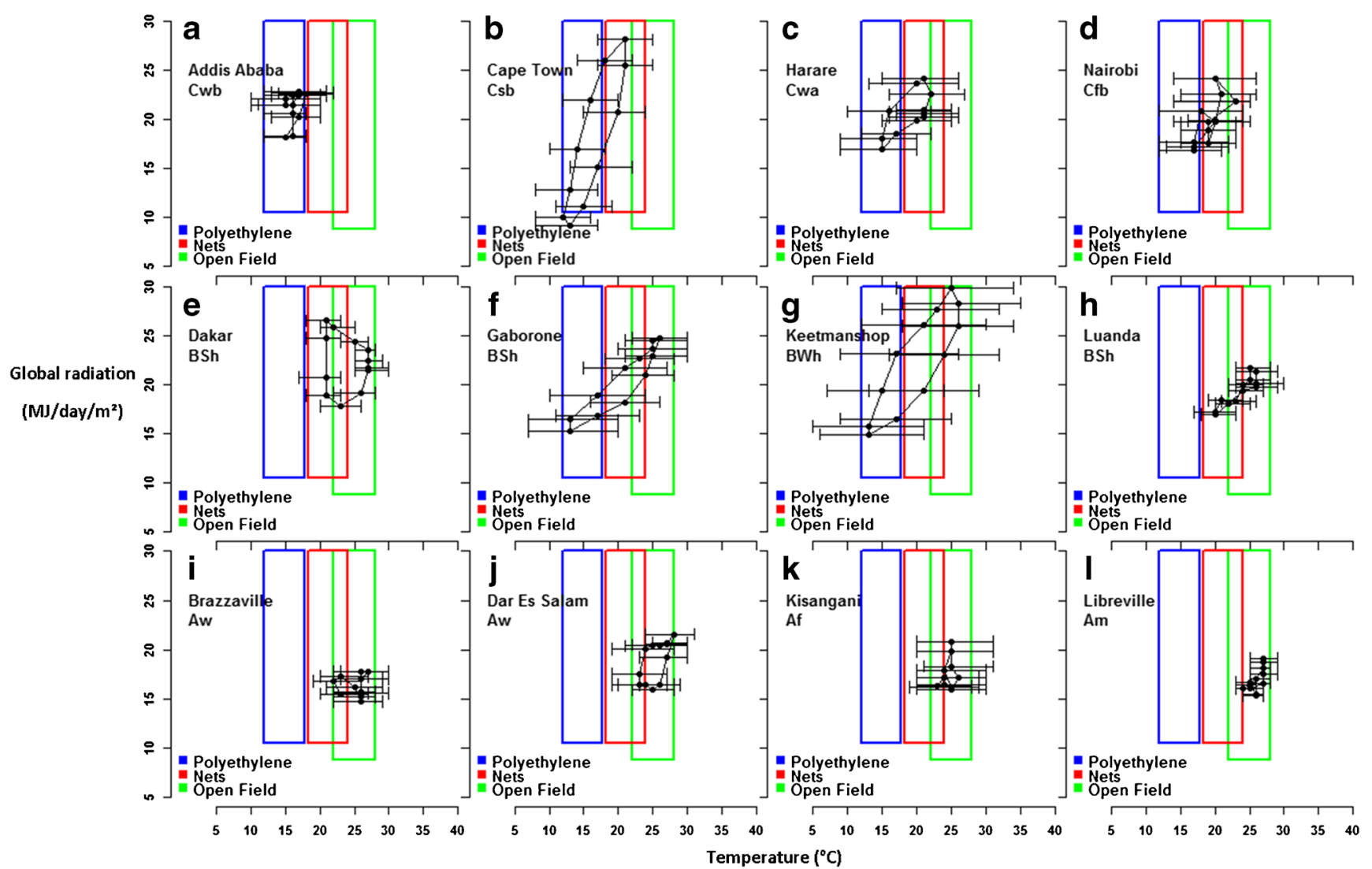

Fig. 3 Adaptation of net houses and polyhouses to climatic conditions, i.e., temperature and global radiation, in different locations in SSA, Addis Ababa (Ethiopia, A), Cape Town (South Africa, B), Harare (Zimbabwe, C), Nairobi (Kenya, D), Dakar (Senegal, E), Gaborone (Botswana, F), Keetmanshop (Namibia, G), Luanda (Angola, H), Brazzaville (Republic of Congo, I), Dar Es Salam (Tanzania, J), Kisangani (Democratic
Republic of Congo, K), Libreville (Gabon, L). Range of temperature and global radiation suitable for the development of a tomato crop in the open field, net house and polyhouse are represented in light gray, gray and dark gray, respectively. Monthly temperature averages are represented in terms of minimum, mean and maximum highland climate, a greenhouse covered with polyethylene would provide more favorable temperatures to tomato crop development all year round than the ones in open field and in a greenhouse covered with nets (Fig. 3A).

Under arid climates, cultivation of tomato in greenhouses covered by polyethylene films would be limited by high temperature problems for most of the year (Fig. 3E to $\mathrm{H}$ ) and all year round in equatorial areas (Fig. 3I to L). In areas with arid climates, the use of insect proof nets, although they reduce the impact of covers on temperature, would induce high temperature issues during periods ranging from 4 months in Keetmanshop (Fig. 3E) to 7 months in Luanda (Fig. $3 \mathrm{H}$ ). The favorable period for tomato cultivation under net covers would be shorter under an equatorial climate, ranging from 1 month in Libreville (Fig. 3L) to 4 months in Kisangani, Brazzaville and Dar Es Salam (Fig. 3K). It is worth noting that the use of covers would allow off season tomato production in Gaborne (Fig. 3F) and Keetmanshop (Fig. 3G) during the cold season thanks to more favorable temperatures.
This first effort to determine the suitability of tomato greenhouse cultivation with climatic conditions in SSA provided evidence that temperature is a serious issue in closed shelters with no cooling system, i.e. fogging, fans, under the arid and tropical climates that are the main climates in SSA. Even if the use of insect proof nets mitigates the detrimental impacts of covers on temperature and air moisture, greenhouse cultivation is restricted to cooler months and would offer during this period the opportunity to produce out season vegetables.

It thus appears that, because of the climatic conditions, low-tech greenhouses are not suitable for use all year round in most of areas in SSA and this restriction of the cultivation period should be taken into considered in cost benefit analyses.

\subsubsection{Control of insect pests with protected cultivation}

Control of insect pests is an inescapable necessity for vegetable farmers in Africa since they can cause yield losses of up to $100 \%$. Many smallholders consider the use of chemical inputs 
as a strategy to ensure their production and their livelihood. However, the use of pesticides can no longer be considered as a solution to control insect pests because of the development of resistance (Martin et al. 2002; Carletto et al. 2010; Houndété et al. 2010; Agboyi et al. 2016) and because of their impacts on environment and human health (Wilson and Tisdell 2001; De Bon et al. 2014). Research has been underway for more than 10 years on the use of insect proof nets over vegetable crops as a generic protection to control insect pests while ensuring sufficient natural ventilation. Insect proof nets are believed to be a suitable solution to reduce the use of insecticides and to protect vegetable crops from the emergence of new devastating insect pests for which chemical treatments are not effective (Martin et al. 2014b). Several studies on cabbage (Brassica oleracea L.) in Benin (Martin et al. 2006; Licciardi et al. 2007) and later in Kenya (Kiptoo et al. 2015; Muleke et al. 2012, 2014), on tomato (Lycopersicon esculentum Mill.) (Gogo et al. 2014a; Saidi et al. 2013; Gogo et al. 2012), and on green beans (Phaseolus vulgaris L.) in Kenya (Gogo et al. 2014b) have reported the advantage of using insect proof nets to exclude insect pests. However, contradictory studies on hot pepper (Capsicum chinense Jacq.) in Uganda (Karungi et al. 2013), on cabbage in Benin (Simon et al. 2014; Martin et al. 2013) and in Kenya (Kiptoo et al. 2015), on tomato in Caribbean islands (Holt et al. 2008) showed that insect nets provide insufficient protection against insect pests.

Several studies have been dedicated to optimizing mesh size to ensure sufficient ventilation to limit heat load and efficient physical protection against insect pests (Saidi et al. 2013). This task is not easy since the optimum size varies with the crop, the pressure from insect pests, and climatic conditions. The capacity of nets to exclude insect pests has been widely studied in net screens used for greenhouse ventilation (Bell and Baker 2000; Bethke et al. 1994; Bethke and Paine 1991). Results showed that there is no clear relationship between mesh size and the pest exclusion efficiency (Bethke and Pain 1991). Berlinger et al. (2002) reported marked variations in whitefly penetration of the same screen in laboratory conditions. Similarly contrasted results of field trials have been reported on the efficiency of nets to exclude insect pests. It is difficult to compare insect proof nets since several mesh features including size, geometry and blending, i.e. knitted or woven, influence their insect exclusion capacity (Bethke et al. 1994). Depending on the authors, mesh size is given either as the number of holes per inch or as the size of the hole, but this does not apply if the mesh is not square or is woven. In addition, the difference in nets efficiency could also be due to slipping of unevenly woven yarn.

With certain exceptions, large pests (Lepidoptera, Diptera) are well controlled whereas small pests (Hemiptera, Thysanoptera, Mite) are not. In most field experiments, fruit worms were well controlled by a large mesh regardless of the crop and the mesh size tested (Martin et al. 2014b). Some bigger insect pests such as Spodoptera littoralis and Tuta absoluta can also circumvent physical protection by laying their eggs on the nets and their very small prenatal larvae then pass through the mesh (Biondi et al. 2015; Martin 2015; Talekar et al. 2003; Simon et al. 2014). Our overview of the literature indicates that nets, whatever their mesh size, cannot completely exclude small insects pests such as aphids, thrips, white flies and mites, but they can reduce and delay infestation of the crop (Gogo et al. 2014a; Kaur et al. 2010).

Experiments on tomato in Kenya showed that nets with mesh size of $0.4 \mathrm{~mm}$ reduced aphid populations more efficiently than with a mesh size of $0.9 \mathrm{~mm}$ (Gogo et al. 2014a). Contradictory results were obtained on cabbage in Benin since similar nets promoted the development of aphids and the finest mesh size did not improve protection against insect pests (Simon et al. 2014). Similarly, modeling approaches used by Holt et al. (2008) revealed that nets used on tomato crops without insecticide-treated strips can promote the development of whiteflies.

It is worth noting that the physical protection provided by insect proof nets is not specific. Use of covers on crops is therefore a suitable alternative to face changes in pest pressure related to the emergence of new insect pests. However the side effect of the lack of specificity of net exclusion concerns natural enemies. It is believed that nets can favor the development of some insect pests because of the exclusion of natural enemies and more favorable climatic conditions, including an increase in air moisture and shade. Results on cabbage in Benin suggested that removing nets during the day would favor natural predation and avoid bursts in populations of insect pests (Licciardi et al. 2007; Simon et al. 2014). Actually, the use of biological control is an effective and environmentally friendly alternative to complete protection against insect pests provided by covers. Biological pest management is facilitated in closed shelters since it reduces the dispersion of parasitoids and predators and increases their development because of favorable climatic conditions (Yang et al. 2014). However biological control in SSA is limited by the affordability of auxiliary insects that are adapted to tropical climatic conditions. There is thus a need to identify indigenous natural enemies in SSA to extend biological control. In parallel to biological control, in the case of entomophilous crops, such as tomato, cantaloupe or eggplant, excluding pollinators could also be an issue. A study on cantaloupe (Cucumis melo L.) in Senegal reported that removing the covers of small tunnels at the onset of fruiting to allow open pollination was detrimental to the crop because of damage caused by insect pests (Vaissiere and Froissart 1996). These authors reported that the best results were obtained by maintaining covers throughout crop development and by introducing pollinators inside the shelters. The use of parthenocarpic varieties or mechanical vibrations 
of plants are alternative ways to avoid the problem of pollination in closed shelters.

Several studies have been conducted to improve the capacity of nets to exclude insect pests by increasing their repellent effects including irritancy, odor masking, and visual masking. The use of treated nets was found to be an effective alternative to increase irritancy of nets and to control aphids on cabbage (Martin et al. 2013), i.e. using alphacypermethrin, mites on African eggplant (Solanum macrocarpon L.) (Martin et al. 2010), i.e. using dicofol, and whiteflies on tomato (Martin et al. 2014a), i.e. using alphacypermethrin. However, it is worth noting that treated nets may also have a negative impact on auxiliary populations (Martin et al. 2013) and that there is a risk of insecticide diffusion from nets to crops due to rain or leaching of irrigation water. To avoid the impacts of insecticides on the environment and on human heath, use of treated nets with repellent plant extracts may be a viable alternative (Deletre et al. 2016). Research has also been conducted to increase the visual masking capacity of covers by changing their color. Lower levels of infestation by aphids and whiteflies on tomato and bell pepper (Capsicum annuum L.) crops were reported under tunnels made of yellow and pearl nets than under black and red nets (Ben-Yakir et al. 2012). These differences in infestation were explained by changes in the spectrum of light transmitted by the nets. These results are in line with the results of a study by Kumar and Poehling (2006) who reported lower rates of infestation of tomato crops by sucking insects in a greenhouse covered with UV blocking covers. However, the impact of optical features of covering materials should be considered with caution since changes in light composition are also known to affect plant physiology, including fruit and vegetable quality (Singh et al. 2015; Selahle et al. 2015; Ntsoane et al. 2016; Tinyane et al. 2013) and the synthesis of secondary metabolites involved in plant defenses against insect pests (Paul and Gwynn-Jones 2003), as well as the development of cryptogrammic disease, naturals enemies and pollinators (Raviv and Antignus 2004; Reuveni and Raviv 1997; Antignus 2014).

It was recently reported that a combination of physical protection with a push-pull strategy using aromatic basil (Ocimum basilicum L.) as companion plant reduced infestations of tomato plants by whiteflies (Mutisya et al. 2016). This study suggested that the effect of aromatic plants on whiteflies may be enhanced by nets because of higher concentration of volatile compounds.

In conclusion, there is a consensus that PCT is not a silver bullet against insect pests and they have to be included in Integrated Pest Management (IPM) combining several control techniques such as (i) biological control, (ii) chemical treatments of the net, or (iii) the use of companion plants.

\subsubsection{Changes in cropping systems induced by protected cultivation techniques}

The use of covers does not only require changes in cultural practices to control insects, but modifies the entire cropping system since it also affects the functioning of crops and the soil (Table 1).

The modification of climatic conditions by covers requires adaptation of the cultivars used, since they perform differently in these specific environments (Cheema et al. 2014). Use of varieties with high resistance to cryptogrammic diseases is particularly recommended in the case of cultivation in closed shelters because of the increase in air moisture. The physical support provided by high shelters encourages producers to use trellising systems to cultivate indeterminate or climbing varieties since it facilitates crop handling, increases the yield and extends the production period. In the case of tomato (Lycopersicon esculentum Mill.), yields of determinate varieties cultivated in the open field usually range between 40 and $100 \mathrm{t} \mathrm{ha}^{-1}$ depending on the agro climatic conditions and cultural practices with a cultivation period lasting 3 to 4 months in contrast to yields of up to $700 \mathrm{tha}^{-1}$ and a production period of 11 to 12 months for indeterminate tomatoes (Heuvelink 2005).

To control the soil water balance, fertility, and sanitary quality, PCTs also require changes in soil management practices. Irrigation management has to be adapted to PCTs since they decrease crop evapotranspiration and rain feed. The sanitary quality of soil and its fertility are also affected by vegetable cultivation in non-moveable shelters as a result of unbalanced crop rotations limited to high value vegetable species such as tomato, sweet pepper (Capsicum annuum L.) and cucumber (Cucumis savitus), which have high nutritional requirements and are also highly susceptible to root knot nematodes and bacterial wilt. Similarly, it is more challenging to integrate agro-ecological practices aimed at increasing soil sanitary quality and fertility, such as intercropping and fallow, in protected cultivation cropping systems because of profitability issues. To overcome soil-borne disease and fertility issues, large producers often switch to soilless cultivation, which increases investments and production costs. Grafting is an alternative environmentally friendly and effective way to improve water and nutriment uptakes and reduce the impacts of soil borne diseases and pathogens when genetic resistances are available (Lee and Oda 2010; Schwarz et al. 2010; Louws et al. 2010). This requires identifying a suitable combination of scion and rootstock with higher yield and resistances to abiotic and biotic stress while preserving the quality requirements of the fruit or vegetable. Although grafting is widely used in Asia, it is not widespread in Africa (Keatinge et al. 2014). To introduce grafting systems in Africa, a vibrant and effective seedling system is needed, which is currently only the case in Ethiopia. 
Table 1 Comparison of intended and side effects of protected cultivation techniques. Effects has been expressed from 0, i.e. no impact, to +++, i.e. strong impacts

\begin{tabular}{|c|c|c|c|c|c|c|c|}
\hline & $\begin{array}{l}\text { Plastic } \\
\text { mulch }\end{array}$ & $\begin{array}{l}\text { Row cover } \\
\text { (polyethylene) }\end{array}$ & $\begin{array}{l}\text { Row covers } \\
\text { (nets) }\end{array}$ & Shade nets & $\begin{array}{l}\text { Rainy } \\
\text { shelters }\end{array}$ & $\begin{array}{l}\text { Greenhouse } \\
\text { (polyethylene) }\end{array}$ & $\begin{array}{l}\text { Greenhouse } \\
\text { (nets) }\end{array}$ \\
\hline $\begin{array}{l}\text { Adapted to high crops (indeterminate tomatoes, } \\
\text { pepper, climbing beans...)/low crops (cabbage, } \\
\text { lettuce, French beans...) }\end{array}$ & Yes/Yes & $\mathrm{No} / \mathrm{Yes}$ & No/Yes & Yes/Yes & Yes/Yes & Yes/Yes & Yes/Yes \\
\hline Opportunity to set up trellising systems & 0 & 0 & 0 & + & + & +++ & +++ \\
\hline Increase of soil temperature & +++ & ++ & + & ++ & + & + & 0 \\
\hline Increase of air temperature & 0 & +++ & ++ & + & + & +++ & + \\
\hline Increase of air moisture & 0 & +++ & ++ & 0 & 0 & +++ & + \\
\hline Reduction of evapotranspiration. & +++ & +++ & ++ & + & + & +++ & ++ \\
\hline Reduction of rain-fed & +++ & +++ & + & + & +++ & +++ & + \\
\hline Shading effect & 0 & ++ & + & +++ & ++ & ++ & + \\
\hline Protection against heavy rain impacts & +++ & +++ & ++ & ++ & +++ & +++ & ++ \\
\hline Protection against strong winds & 0 & +++ & ++ & 0 & 0 & +++ & ++ \\
\hline Weeds control & +++ & + & + & 0 & 0 & + & + \\
\hline Protection against aerial insect pests & 0 & +++ & ++ & 0 & 0 & +++ & ++ \\
\hline Protection against soil borne diseases & + & 0 & 0 & 0 & 0 & 0 & 0 \\
\hline Increase of foliar diseases & 0 & +++ & ++ & 0 & ++ & +++ & ++ \\
\hline Movable & Easy & Easy & Easy & Possible & Possible & Difficult & Difficult \\
\hline Life span of covers & $<1$ an & $2-3$ years & $2-4$ years & $2-4$ years & $2-3$ years & $2-3$ years & $2-4$ years \\
\hline Facilitated access to crops & Yes & No & No & Yes & Yes & Limited & Limited \\
\hline Cost $/ \mathrm{m}^{2}$ & $0.04-0.6 \$$ & $0.09-0.1 \$$ & $1.11-1.32 \$$ & $2-5 \$$ & $2-5 \$$ & $5-35 \$$ & $5-35 \$$ \\
\hline
\end{tabular}

In conclusion, PCT considerably modifies the management of cropping systems in terms of (i) crop rotations and (ii) cultural practices, i.e. choice of cultivars, irrigation, fertilization and labor. Side impacts of PCT, i.e. exclusion of auxiliary insects, increase in temperature and air moisture, and soil fertility and sanitary issues, have to be offset by cultural practices that tend to increase the level of artificialization of the agrosystem. As a result, PCT seems to be an ongoing process to better control plant environment causing new agronomic and economic constraints. This raises the question of the profitability and the suitability for smallholders of such practices which disrupt open field cultivation and require higher investment.

\subsection{Suitability of protected cultivation techniques for the socio-economic context of smallholders}

Protected cultivation tends to artificialize cropping systems to create optimum conditions for plant development, and improve yields and the quality of the products. Better control of the crop environment requires investments in more sophisticated equipment that increase the fixed cost of production. The profitability of protected cultivation relies on the capacity to obtain sufficiently higher yields and sales prices to offset the increase in fixed costs. Higher sales prices can be obtained with PCT by exploiting niche markets that are not accessible with open field production. The products of PCT have added value thanks to the improved quality of vegetables and/or offseason production.

Consequently, the economic interest of PCT depends on its ability to better respond to market requirements than open field production. Since PCT requires higher investments and specific skills, this raises the questions of the accessibility of these techniques to small-scale producers, and of the technical support and policies required to promote these technologies.

First we discuss the capacity of PTC to improve crop productions, then we focus on the profitability of these techniques and finally we identify limitations to the adoption of PCT by smallholders.

\subsubsection{Improvements in crop production with protected cultivations techniques}

Concerning yield, the advantages of protected cultivation vary with the crop and with local agronomic constraints. The use of net covers on crops was reported to increase marketable yields in Kenya by up to $30 \%$ for tomato (Lycopersicon esculentum Mill.) (Saidi et al. 2013; Gogo et al. 2014a), 40\% for green beans (Phaseolus vulgaris L.) (Gogo et al. 2014b) and up to $70 \%$ for cabbage (Brassica oleracea L.) (Kiptoo et al. 2015). In Benin, the use of insect-proof nets on cabbage crops that were removed during the day was reported to increase yields 3.2 times in a first study (Martin et al. 2006) and up to 6 times in a more recent study (Simon et al. 2014). It is worth noting that the effects of nets vary greatly with the climatic conditions and pest pressure since the last mentioned authors revealed that the use of permanent insect proofs nets during the hot season could reduce the yield of the cabbage crop because of excessive temperatures and poor insect pest control (Simon et al. 2014) despite the fact that in Kenya, the use of similar permanent covers increased yield 2.6 fold (Muleke et al. 2014). Similar results were obtained with row covers on tomato since yields increased in Kenya (Gogo et al. 2014a; Saidi et al. 2013) but row covers had the opposite 
effect in Mediterranean conditions because of too high temperatures (Rubeiz and Freiwat 1995).

Yields obtained with PCT vary greatly depending on the producer's location and practices. Tomato yields in low tech greenhouses were reported to vary between $3 \mathrm{~T} \mathrm{ha}^{-1}$ and $291 \mathrm{~T} \mathrm{ha}^{-1}$ in Kenya (Wachira et al. 2014), 95 and $211 \mathrm{~T}$ $\mathrm{ha}^{-1}$ in India (Reddy 2015) and 19 and $150 \mathrm{~T} \mathrm{ha}^{-1}$ in the Beijing region (Chen et al. 2004). Performances of PCT vary also considerably depending on the level of technology used to control the crop environment. In Australia, average tomato yields of 60 tons ha ${ }^{-1}, 160$ tons ha ${ }^{-1}, 340$ tons ha ${ }^{-1}$, and 570 tons $\mathrm{ha}^{-1}$ were reported for cultivation in open field, low-tech greenhouse, medium-tech greenhouse and in hi-tech greenhouse, respectively (Page et al. 2012).

In addition to yield, PCTs have an impact on the quality of crop products. For several crops, including green beans (Gogo et al. 2014b), tomatoes (Gogo et al. 2014a) and cabbage (Vidogbéna et al. 2015a) PCT increased marketable yield and decreased yield losses caused by unsuitable products. The impact of PCT on vegetable quality is linked to the covering materials used. Studies on tomato (Tinyane et al. 2013), sweet pepper (Capsicum annuum L.) (Selahle et al. 2015) and lettuce (Lactuca sativa L.) (Ntsoane et al. 2016) showed that the color of the nets used on crops improved post-harvest behavior and several quality determinants of vegetables including size, color, titratable acidity, total concentrations of soluble solids and of bioactive compounds. Studies on lettuce provide evidence that the impact of covers on vegetable quality depended on the cultivar (Ntsoane et al. 2016).

Another component of quality that can be improved with PCT is a reduction in pesticide residues in vegetables, as the result of reduced use of insecticides. According to crop and agronomic conditions, netting was reported to reduce the use of pesticides by between 70 and 100\% (Martin et al. 2014b).

In addition to increasing the yield and the quality of the products, one of the main advantages of PTC is being able to exploit opportunities for off-season vegetable production. A study of 193 markets in seven African countries revealed that fruits and vegetables were the commodities with the highest seasonality (Gilbert et al. 2016). These authors reported that the average price of tomatoes varied by more than $60 \%$ over the year. Market trends are explained by the seasonality of vegetable crops which are greatly dependent on climate conditions and shifts in crop pest pressure. Moreover, the marked fluctuations in the sales price of vegetables are strengthened by their perishability and by the lack of appropriate infrastructures for processing and postharvest preservation. A recent meta-analysis showed that average postharvest losses in SSA ranged between 10.7 and $33.7 \%$ for tomato, between 2.1 and $14 \%$ for beans and reached $43.5 \%$ for leafy vegetables (Affognon et al. 2015).

Mitigation of the impacts of climate hazards and crops pests by PCT enables the production of off-season vegetables and the fulfillment of market requirements that cannot be met with open field cultivation.

Studies in Ghana (Attoh et al. 2014) South Africa (Malherbe and Marais 2015) and Ethiopia (Tegen et al. 2016), demonstrated the interest of PTC to overcome biotic and abiotic constraints and to extend the production period to obtain higher market rates.

PCT also makes it possible to produce in more challenging agronomic contexts such as urban areas thanks to more efficient use of land and resources. The capacity of PCT to meet urban agricultural challenges is worth noting since this form of farming is expected to play a major role in the supply of food and the creation of jobs in cities in developing countries (De Bon et al. 2010). China's agricultural policy has been to support the development of PCT to promote urban agriculture and to ensure the food self-sufficiency of cities, (Yi-Zhang and Zhangen 2000; Lang and Miao 2013; Gale et al. 2013). It has been estimated that around $50 \%$ of the vegetables consumed by the 18.6 million inhabitants of Shanghai are produced locally (Lang and Miao 2013).

In conclusion, PCT has several agronomic advantages that enable the production of high quality vegetables and offseason products, which can be profitable if producers succeed in exploiting market opportunities.

\subsubsection{Profitability of protected cultivation}

The economic performances of PCT rely on the balance between costs and benefits and the profit that can be made with PCT compared to open field cultivation. The first difficulty encountered in trying to establish the profitability of PCT is the marked difference in increases in yield obtained in PCT systems compared to open field cultivation. A cost-benefit analysis was conducted in Kenya to compare the profitability of tomato (Lycopersicon esculentum Mill.) cultivation in low tech greenhouses and in the open field (Wachira et al. 2014) and revealed that average yields in greenhouse were about 10 times higher than in the open field. As a result, the authors reported that net profits per square meter were 13 times higher for tomato cultivation in greenhouse than in the open field even though fixed costs, i.e. the sum of all costs that do not vary with the production, were on average more than 60 times higher for greenhouse farming. It is worth noting that even bigger differences in net profits of tomato cultivation in greenhouse are reported, i.e. from -1.3 to $8.9 \$ \mathrm{~m}^{-2}$, than in open field cultivation, i.e. from -0.04 to $0.48 \$ \mathrm{~m}^{-2}$, as a result of higher variations in yield, i.e. 3.3 to $291 \mathrm{t} \mathrm{ha}^{-1}$ versus 0 to $34.6 \mathrm{t} \mathrm{ha}^{-1}$. These results are evidence that the higher profits that can be obtained with greenhouse cultivation are related to more risky speculation because of higher fixed costs and such variable yields.

Another cost-benefit analysis in Benin showed that the use of basic low tunnels for cabbage (Brassica oleracea L.) 
cultivation was profitable because of an increase in yield, higher farm gate prices related to improved quality and a 68-95\% reduction in pesticide costs (Vidogbéna et al. 2015b). One important finding of this study was that insect nets ensured both more stable costs and more stable yields than non-netted crops in the open field, generating more stable cash flows for producers. The same study revealed that for a 3 year period, i.e. corresponding to the lifespan of high quality nets, producers' profits were three time higher than those obtained with current practices based on the use of pesticides.

A study conducted in the northern plains in India revealed that, contrary to in greenhouses, cultivation of cucurbits under plastic row covers and in walk in tunnels is only profitable off season i.e. in winter, because of the detrimental effect of the covers on temperature and air moisture (Singh et al. 2005).

In contrast to the previously mentioned studies, several authors did not recommend the use of PCT because of insufficient return on investment, for example for the cultivation of okra (Abelmoschus esculentus) using row covers in Alabama (Gordon et al. 2010), or for the cultivation of melon (Cucumis melo L.) under row covers in Mexico (Farias-Larios et al. 1996), or for the cultivation of tomatoes under rain shelters in Taiwan (Midmore et al. 1997).

These contrasted results suggest that the profitability of PCT depends on the answer to the following question, how does PCT allow producers to better respond to market requirements and to get higher prices for their products?

PCT can be a good way to produce high quality vegetables that respect the quality standards of export markets and stringent limits on maximum residue levels of pesticides in foodstuffs. In a review article (Maertens et al. 2012) showed that in SSA, smallholders' access to export markets varies greatly depending on the crop and the country. As an example, they reported that $50 \%$ of fruit and vegetable exports are provided by smallholders in Kenya, whereas in Zimbabwe smallholders provide less than $10 \%$ of exports. In Senegal, although more than $50 \%$ of green bean exports are sourced from smallholders, smallholders contribute nothing to tomato exports. These authors underlined that smallholder access to exports market depends on their production capacity and on local competition with large commercial farms. They also reported that smallholders' access to those markets is tending to decrease due to increasing food quality and safety standards.

For local and regional markets, the opportunity represented by PCT to reduce the use of pesticides remains under-valued. In most cases, there is no difference in farm gate prices between insecticide free and treated crops because of the lack of labeling and regulations (Gogo et al. 2014a). In contrast, improvements in the appearance of vegetables such as color or size, thanks to PCT, were reported to be reattributed by increasing marketable yield and upgrading vegetables (Vidogbéna et al. 2015a). The profitability of PCT is also hindered by the absence of organization of local markets and supply chains, which reduces producers' marketing alternatives and prevents them from identifying opportunities for off-season production.

Ultimately, the profitability of PCT for smallholders would be increased by ensuring better valorization of high quality production through better access to export markets and/or the emergence of a premium local/regional vegetable market in sub-Saharan countries.

\subsubsection{Brakes on the adoption of protected cultivation techniques by smallholders}

Although efforts have been underway for decades to transfer and develop low tech PCT adapted to SSA climatic conditions and that smallholders can afford, adoption of these techniques by producers remain limited. The development of PCT in Tanzania is an interesting example that reveals the potential impediments to upscaling these technologies to smallholders. Since the beginning of the 2000s, Tanzania has seen the rapid appearance of greenhouses owned by foreign investors for flower cultivation and seed production, following the already more-advanced and well-established Kenyan greenhouse cultivation sector. This drove the development of the horticultural sector through the development of private associations and the growth of agribusinesses. These technologies have been the subject of growing interest by local producers, especially after several major pest outbreaks and under the impulse of greenhouses companies. Unfortunately, producers faced an wide range of difficulties, from the unsuitability of the greenhouse design for local climatic conditions, the lack of technical support, to the absence of remunerative markets. These issues led some of them to simply abandon protected cultivation and return to open-field farming.

There are many examples in Africa and elsewhere of failed projects in which technologies were transferred to unsuitable areas (Deininger and Byerlee 2010). Low-tech PCTs are particularly concerned by this issue since, as underlined in section I.A, the sustainability of such technologies is restricted to specific climatic conditions, i.e. a combination of location and of certain periods of the year. Several authors reported that investment capacity is still one of the main limiting factors of protected cultivation, although low-tech PCTs have been designed to be affordable by smallholders, (Bhatnagar 2014; Chatterjee et al. 2013; Armenia et al. 2013; Vidogbéna et al. 2015a). As is true for other technologies, the upscaling of PCT to smallholders is hindered by the marked heterogeneity of farms in terms of income, production objectives and access to inputs (Chikowo et al. 2014). The promotion of PCT should preferentially target resource-endowed producers rather than resource-constrained households since resource-endowed producers already have access to priority technologies to increase crop productions including fertilizers, improved cultivars and irrigation system. 
In Benin, a rapidly reached break-even point and much higher profitability of net use than current cultural practices based on pesticide use has been reported (Vidogbéna et al. 2015b). Nevertheless, spraying pesticides appears to producers to be less risky since it is a well-known practice and, in contrast to nets, it is a curative method that can be readily used and adjusted at any stage of crop development.

Skills and knowledge and are also main limits to the adoption of PCT, which requires considerable changes in cropping systems (see section I.C). Studies carried out in India showed that protected cultivation methods remain accessible to only a few farmers although subsidies may cover 50 to $90 \%$ of initial investments partly due to lack of information (Chatterjee et al. 2013; Bhatnagar 2014). This is consistent with the results of studies conducted in Kenya revealing that (i) greenhouse producers had a higher education level than open field producers (Wachira et al. 2014), and (ii) greenhouse performances were closely related to technical support provide to farmers (Omoro et al. 2015).

The success of the vegetable basket plan launched at the end of the 1980s in China is an inspiring example of the success of a policy to promote protected cultivation technologies by providing technical support, access to capital, and to organized marketing. The Chinese plan aimed to improve the supply of food to cities notably by subsidizing the construction of greenhouses and developing networks of demonstration farms to promote new modes of production (Gale 2013). Since imported greenhouses were too large and expensive for smallholder producers, efforts were made to propose low tech and effective greenhouses ( $\mathrm{Gu} 2009)$. As a result, the area dedicated to greenhouses cultivation in China increased from $0.2 \%$ in 1980 to $11.2 \%$ in 2000 (Liu et al. 2004). From the late 1990s to 2011, Chinese exports of vegetables have more than tripled (Gale et al. 2013). Although nowadays it is considered that China's role in the world vegetable market has peaked (Gale et al. 2013), China remains the world's leading producer of vegetables and is also the leading producer of plastic greenhouses worldwide (Gale et al. 2013; Chang et al. 2013).

\subsection{Environmental impacts of protected cultivation}

Little is known about the environmental impacts of protected horticulture in SSA, and especially about the low-cost protected cultivation techniques for smallholders analyzed in this paper. First global environmental assessments using life cycle assessment (LCA) have confirmed the high potential impacts of urban garden vegetables in Africa with a case study of tomato production in southern Benin \{(Perrin et al. 2015; Perrin et al. 2017) but low-cost protected cultivation techniques such as insect-proof nets have never been assessed using such a global and multi-criteria assessment tool. Like open-field vegetable cropping systems, protected vegetable cropping systems use fertilizers, pesticides, energy and water. Production, transport, use and end-of-life of these agricultural inputs have impacts on the environment through the consumption of abiotic resources and the release of chemical compounds into the soil, air and water. The introduction of supplementary inputs in vegetable cropping systems, including plastics for covers, iron or wood for the frames, and energy based equipment that consumes energy, raise concerns in relation to their production and transport but also to their low biodegradability and their potential impacts on terrestrial and marine ecosystems (Jambeck et al. 2015; Sharma and Bansal 2016).

A recent study by Steinmetz et al. (2016) reviewed the environmental effect of plastic mulches, underlining their negative impact on soil fertility because of changes in soil structure, enhancement of pesticide runoff, the production of micro plastic debris and a shift in the soil microbial community. They also discussed the difficulty involved in recycling plastic mulches used for only a period of a few months because of the cost of collecting and sorting and the technical problems involved in treating plastic contaminated with soil and agrochemicals. These reviews underlined the need for an overview of all the environmental impacts associated with cropping systems, from cradle-to-grave. An evaluation and comparison of the environmental impacts of protected and open field cropping systems with a tool such as life cycle assessment is greatly needed. Life cycle assessment is an internationally standardized methodology (ISO 14040-2006 and ISO 14044-2006) that accounts for the entire life cycle of a product, from resource extraction for inputs to waste disposal, in the assessment of the environmental impacts of production methods and systems. Yet, using such a method in the SSA context is a huge challenge because of the variability of existing systems and the scarcity of data.

Based upon the first alerts concerning open-field urban and peri-urban gardens including the concentrations of pesticides measured in rivers in Senegal (Cissé et al. 2003) and Ivory Coast (Traoré et al. 2006; Cissé et al. 2003) and several analyses of the risks for human health and for the environment of these cropping systems (De Bon et al. 2014; De Bon et al. 2010; Orsini et al. 2013), a first global assessment with LCA was performed on tomatoes produced in urban gardens in southern Benin (Perrin et al. 2017). Results revealed potential impacts for the environment and for human health from 4 to 23 fold - expressed per kilogram of fresh tomato-higher than the impacts of tomatoes grown in European cropping systems even in heated greenhouses. These very high impacts were explained by the low and variable yields of crops, the low performance of irrigation systems in terms of fuel consumption, the high emissions of nutrients and the excessive use of insecticides. In this context, can the use of plastic covers help farmers reduce their impacts per $\mathrm{kg}$ of product? It is argued that the higher yields obtained with protected cultivation as well as the reduced use of pesticides and the higher water efficiency 
can mitigate the environmental impacts of these technologies based on the use of plastic (Van Lenteren 2000).

Life cycle assessment has most often been used for protected and open-field horticulture in European and Mediterranean countries. As an illustration, Table 2 presents the global warming potential and several input rates per $\mathrm{kg}$ of tomato obtained from some of these studies on tomato production. Marked differences in environmental impacts were found depending on the levels of technology used for tomato cultivation, the production period, and the location. Tomatoes produced all year round in soilless heated greenhouses had the highest impacts. For instance, the global warming potential of these systems listed in Table 2 was on average more than ten times higher than the one of open field cultivation. Greenhouse gas emissions from these tomato production systems showed more than $80 \%$ of energy consumption was used for heating (Page et al. 2012). Not surprisingly, the authors of these studies concluded that the use of artificial methods to produce out-of-season vegetables in winter in temperate regions was not to be recommended from an environmental perspective. The studies reviewed in Table 2 indicate that the impact of tomatoes produced in unheated greenhouses is comparable with that of tomatoes grown in the open field. The studies agree that for tomato cultivation, water use efficiency is higher in the greenhouse than in the open field. This is consistent with a study on lettuce showing that hydroponic techniques reduce water use more than ten times in comparison with open field systems (Barbosa et al. 2015).

Several authors also reported that protected cultivation of tomato made it possible to reduce the use of pesticides (Martínez-Blanco et al. 2011; Van Lenteren 2000; Yang et al. 2014). This is consistent with studies on green beans (Romero-Gámez et al. 2009), lettuce (Barbosa et al. 2015) and strawberries (Khoshnevisan et al. 2013) showing that greenhouse cultivation reduces the use of pesticides and water per kilogram of vegetable produced.

Nevertheless, the quantity of pesticides used in protected cultivation appears to vary considerably with the level of technology used and the producer's skills. In the Netherlands, where tomato yield is more than five times higher than in Almeria, the quantity of active pesticide ingredients used per kilogram of tomato produced was estimated to be about 20 times lower (Peet and Welles 2005).

The production of the infrastructure of non-heated greenhouse has been described as one of the hotspots of such production systems, accounting for between 10 and $48 \%$ of the global warming impact (Payen et al. 2015; Boulard et al. 2011; Martínez-Blanco et al. 2011; Torrellas et al. 2012). Several authors pointed out that the environmental burdens of greenhouse construction would be considerably reduced by using long term and/or recycled materials (MartínezBlanco et al. 2011; Romero-Gámez et al. 2009). The construction of low tech polyethylene greenhouse with a wooden framework was reported to have a lower environmental impact than glasshouses with zinc coated steel, with respect to global warming, human toxicity and terrestrial ecotoxicity indicators (Russo and Scarascia Mugnozza 2004). This is mostly explained by the fact that emissions of zinc due to the corrosion of the galvanized steel frame of the greenhouse contaminates water and ultimately affect human health. The importance of this contribution to the human health impact was also demonstrated in a case study of tomato in Rwanda produced in the open field and greenhouses (Basset-Mens 2016). The lifespan of the greenhouse materials depends on intrinsic factors, including its polymers, on the additives used, and on its thickness, and on extrinsic factors including climate conditions and use of agrochemicals. The life span of mulching films is considered to be a few months, while the life span of polyethylene insect proof nets is 2-4 years (Vidogbéna et al. 2015b), 1-3 years for UV stabilized polyethylene film for greenhouses (Reddy 2015), 5-10 years for rigid plastic sheets (Scarascia-Mugnozza et al. 2012; Reddy 2015) and 30 years for glass panes (Boulard et al. 2011).

Management of wastes also has a major influence on the environmental burden of protected cultivation methods. A life cycle assessment of green bean cultivation in low tech greenhouse in Spain showed that the recycling of the plastic and steel wastes used for the structure, covers and irrigation was the process in the production system that had the greatest impacts on toxicity to human and on abiotic-resource depletion (Romero-Gámez et al. 2009). The management of plastic wastes differed considerably from that in the LCA of tomato cultivation reviewed in Table 2, since they were considered to be totally re-used or recycled (Payen et al. 2015; Muñoz et al. 2007), partially recycled, i.e. between 20 and 50\%, (Boulard et al. 2011; Martínez-Blanco et al. 2011) or totally landfilled (Torrellas et al. 2012). These differences between authors reflect the variations in waste management between locations. Statistics indicate that on average, around 38\% of European plastic wastes are landfilled (PlasticsEurope 2015). The presence of impurities, including soil and pesticides, cause technical problems and increases the cost of recycling of agricultural plastic wastes (Briassoulis et al. 2013). An alternative to recycling is energy recovery from plastic waste that takes advantage of the high calorific value of these materials and could be used as a replacement for regular fuel. It is estimated that the calorific value of polyethylene, which is used in the vast majority of agricultural plastic wastes, is similar to that of diesel fuel and higher than that of natural gas (ScarasciaMugnozza et al. 2012; Briassoulis et al. 2013). In LCA, particular attention should be paid to waste management processes especially to estimate terrestrial ecotoxicity.

Perrin et al. (2014) undertook a thorough review of the literature available on LCA for vegetables including a typology of cropping systems (heated or cold greenhouses with or without soil and open field systems under temperate, 


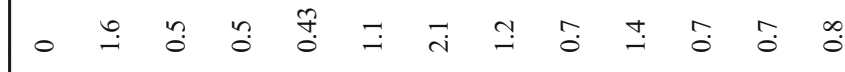

善

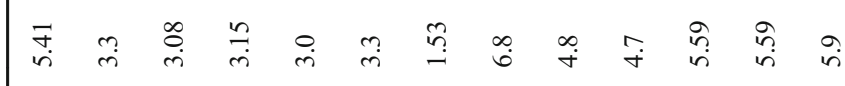

.0ี

○े

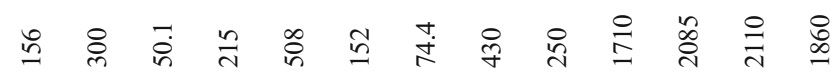

言

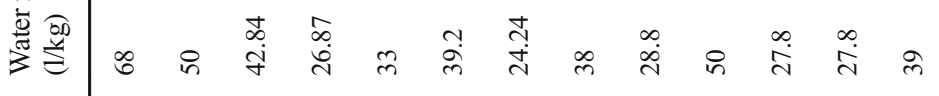

홍

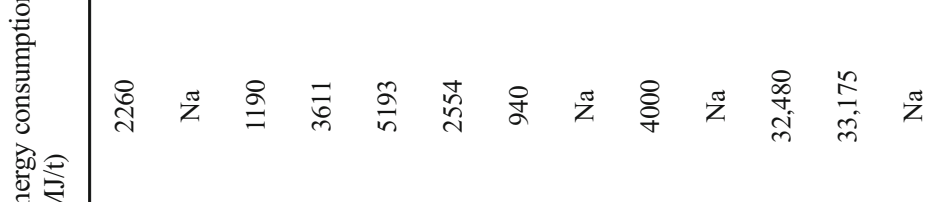

氖这

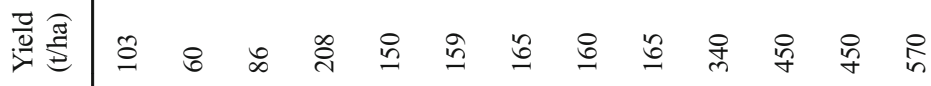

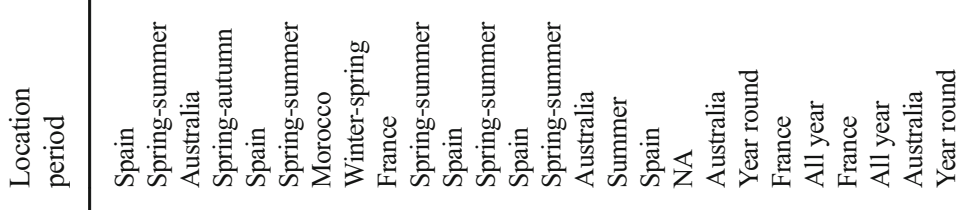

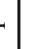

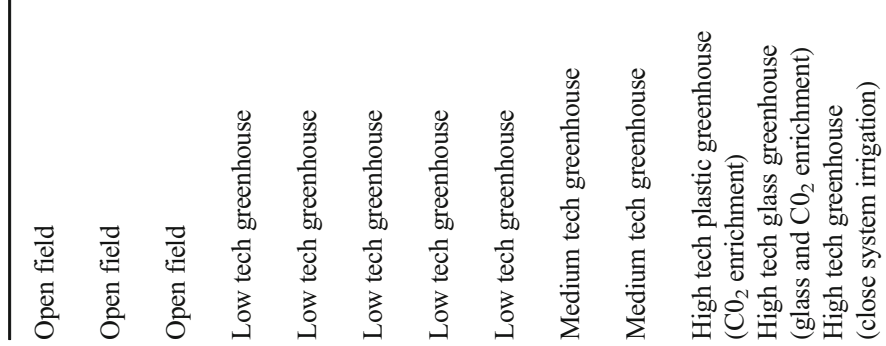


Mediterranean and tropical climates) and the results of LCA, and a critical analysis of the key challenges facing the evaluation of these systems. The results of this review converge with the above conclusions identifying heated greenhouses as the system with the most impact. For this type of cropping system, the sources of energy used to heat the greenhouse represent the key lever for reducing the impacts. Overall, the key sources of variations in the LCA results across all cropping system types were the yield, the use of inputs (energy, infrastructure, auxiliary equipment, fertilizers, and pesticides) but also the assumptions made concerning allocation and substitution procedures. As already mentioned, this study also confirmed that, except for heated greenhouses, the differences between types of cropping system (open-field versus unheated greenhouses) were generally less than the intratype differences due to the diversity of cropping practices. From a methodological point of view, Perrin et al. (2014) highlighted issues of comparability and transparency between studies, but also the lack of accounting of the diversity of cropping systems and of the specificity of the local context in the methods used to estimate field emissions. Field fluxes of phosphorous, pesticides and water and associated impacts: eutrophication, toxicity and water deprivation, although very important for horticultural cropping systems, were often not evaluated in the studies reviewed. In an LCA study on offseason tomatoes grown in Morocco, Payen et al. (2015) demonstrated the importance of including the impacts of water deprivation especially when comparing local versus imported produce across contrasted climatic regions of the world. The non-evaluation of the impacts of pesticide use was often justified by the lack of consensual, reliable and user-friendly methods.

In brief, existing LCA studies on protected compared to open-field horticulture revealed that although protected horticulture can yield more and better quality produce, the extra costs for the environment due to the materials used for protection (manufacturing, transport, recycling and final disposal) and possible energy use for heating or cooling can hinder their expected better eco-efficiency mostly if the technology is not properly managed. The actual impacts per $\mathrm{kg}$ of produce will therefore depend on the efficiency of the use of key inputs per $\mathrm{kg}$ of produce, which is closely linked to both the production conditions of the producers and the quality of management. In Rwanda, Basset-Mens (2016) reported that the environmental impacts of two low tech greenhouses producing tomatoes were highly contrasted. In contrast to the first greenhouse, the second greenhouse was found to have less impact than open field systems, except for human toxicity impacts. The marked difference in the performances of the two greenhouses was attributed to poor farmer practices in the first greenhouse leading to a lower yield despite a higher use of pesticide, fertilizer, and the use of fuel for irrigation.
The potential benefits of protected horticulture in SSA will vary in intensity depending on the region and the farmers' education and ability to manage the technology efficiently. A combination of optimum techniques (mesh size and shape, repellent, biological control), appropriate regions for reducing insect pressure and improving yield, and also training producers in the optimal use of these techniques, should improve the eco-efficiency of vegetable production in SSA. However, these potential benefits will need to be validated through complete and reliable LCA studies using real farm data. From the point of view of environmental evaluation, many challenges face the proper evaluation of these systems in SSA. In the context of data scarcity, they include optimal accounting for the diversity of practices, reliable estimation of field fluxes and related impacts due to organic fertilizers, pesticide applications and water use for irrigation and a proper evaluation of the effect of plastic on soil fertility.

\section{Conclusion}

The success of protected cultivation techniques (PCT) worldwide have encouraged research and projects to transfer these technologies to sub Saharan Africa to overcome agronomic constraints and ensure vegetable production all year round. Efforts have been made to develop low-tech PCT affordable to smallholders and to adapt them to climatic conditions. Contrasted agronomic performances have been reported for low-tech PCT because of poor control of insect pests and climatic conditions. The side effects of covers on climate as well as the lack of equipment to control temperature and air moisture, limit the use of closed shelter to a restricted period of the year. Studies revealed that PCT is not a silver bullet to control insect pests and must be combined with other practices, including biological control, push-pull methods, and chemical treatments. In this review, we underlined that PCT requires considerable changes in cropping system management since cultural practices have to be adapted to exploit the opportunities offered by this technologies, i.e., trellising of indeterminate climbing cultivars and the use of grafted plants, or to offset the agronomic constraints they engender, i.e. water input, pollination, soil-borne diseases, and fertility issues.

The break with existing cropping systems requires providing technical and economic support to small producers for whom investment capacity is a major limitation to the adoption of these technologies. Policies have a major role to play in supporting the development of PCT by organizing the market, providing technical support and enabling access to finance.

The higher fixed costs of PCT increase the economic risk and they have to be offset by increased yield or the opportunity to exploit niche productions to profit from higher sales prices. The identification of niche productions is a main 
challenge for PCT, particularly in local markets since trends in off-season production opportunities are difficult to predict and because quality is poorly reattributed.

Ultimately, PCTs are promising technologies to improve the supply of vegetables in SSA all year round, but their upscaling requires making sure the level of technology used makes it possible to overcome agronomic constraints and suits the socio-economic context of producers. To this end, further research is needed (i) to understand impacts of low-PCT on climatic conditions and on insect pest populations in order to improve their design and combine them with other methods of pest control and (ii) to estimate the profitability of these techniques for smallholders so as to design suitable and affordable cropping systems. Further research is also required to determine whether the increased use of low biodegradable materials such as plastics in PCT does not imply agronomic benefits are obtained at the expense of the environment. If studies conducted in northern countries suggest that the impact of low tech PCTs on the environment is comparable to that of open field cultivation if properly managed, whether these results can be extrapolated to SSA is still not known, given the diversity of cultural practices and the management of wastes.

\section{References}

Abdel-Ghany AM, Al-Helal IM, Alzahrani SM, Alsadon AA, Ali IM, Elleithy RM (2012) Covering materials incorporating radiationpreventing techniques to meet greenhouse cooling challenges in arid regions: a review. Sci World J 2012

Affognon H, Mutungi C, Sanginga P, Borgemeister C (2015) Unpacking postharvest losses in sub-Saharan Africa: a meta-analysis. World Dev 66:49-68

Agboyi L, Ketoh G, Martin T, Glitho IA, Tamo M (2016) Pesticide resistance in Plutella xylostella (Lepidoptera: Plutellidae) populations from Togo and Benin. Int J Trop Insect Sci :1-7

Alexandratos N, Bruinsma J (2012) World agriculture towards 2030/2050: the 2012 revision. ESA Work Pap 3

Altieri MA, Funes-Monzote FR, Petersen P (2012) Agroecologically efficient agricultural systems for smallholder farmers: contributions to food sovereignty. Agron Sustain Dev 32(1):1-13. https://doi.org/10. 1007/s13593-011-0065-6

Antignus Y (2014) Management of air-borne viruses by "optical barriers" in protected agriculture and open-field crops. Adv Virus Res 90:133

Armenia PT, Menz KM, Rogers GS, Gonzaga Z, Gerona RG, Tausa ER (2013) Economics of vegetable production under protected cropping structures in the eastern Visayas, Philippines. Smallholder HOPES - horticulture, people and soil 112

Attoh C, Martey E, Kwadzo G, Etwire PM, Wiredu AN (2014) Can farmers receive their expected seasonal tomato price in Ghana? A probit regression analysis. Sustain Agric Res 3(2): 16

Azandémè-Hounmalon GY, Affognon HD, Komlan FA, Tamò M, Fiaboe KKM, Kreiter S, Martin T (2015) Farmers' control practices against the invasive red spider mite, Tetranychus evansi Baker \&amp; Pritchard in Benin. Crop Prot 76:53-58. https://doi.org/10.1016/j. cropro.2015.06.007
Barbosa GL, Gadelha FDA, Kublik N, Proctor A, Reichelm L, Weissinger E, Wohlleb GM, Halden RU (2015) Comparison of land, water, and energy requirements of lettuce grown using hydroponic vs. conventional agricultural methods. Int J Environ Res Public Health 12(6):6879-6891

Basset-Mens C (2016) Value chain analysis of the tomato value chain from Rwamagana, Rwanda. DG-DEVCO, European Commission, Project BX-19

Baudoin W, Nono-Womdim R, Lutaladio N, Hodder A, Castilla N, Leonardi C, De Pascale S, Qaryouti M (2013) Good agricultural practices for greenhouse vegetable crops: principles for Mediterranean climate areas

Bell ML, Baker JR (2000) Comparison of greenhouse screening materials for excluding whitefly (Homoptera: Aleyrodidae) and Thrips (Thysanoptera: Thripidae). J Econ Entomol 93(3):800-804. https:// doi.org/10.1603/0022-0493-93.3.800

Bempah CK, Agyekum AA, Akuamoa F, Frimpong S, Buah-Kwofie A (2016) Dietary exposure to chlorinated pesticide residues in fruits and vegetables from Ghanaian markets. J Food Compos Anal 46: 103-113. https://doi.org/10.1016/j.jfca.2015.12.001

Bempah CK, Buah-Kwofie A, Enimil E, Blewu B, Agyei-Martey G (2012) Residues of organochlorine pesticides in vegetables marketed in Greater Accra Region of Ghana. Food Control 25(2): 537-542. https://doi.org/10.1016/j.foodcont.2011.11.035

Ben-Yakir D, Antignus Y, Offir Y, Shahak Y (2012) Colored shading nets impede insect invasion and decrease the incidences of insecttransmitted viral diseases in vegetable crops. Entomol Exp Appl 144(3):249-257. https://doi.org/10.1111/j.1570-7458.2012.01293

Berlinger M, Taylor R, Lebiush-Mordechi S, Shalhevet S, Spharim I (2002) Efficiency of insect exclusion screens for preventing whitefly transmission of tomato yellow leaf curl virus of tomatoes in Israel. Bull Entomol Res 92(05):367-373

Bethke J, Paine T (1991) Screen hole size and barriers for exclusion of insect pests of glasshouse crops. J Entomol Sci 26(1):169-177

Bethke J, Redak R, Paine T (1994) Screens deny specific pests entry to greenhouses. Calif Agric 48(3):37-40

Bhatnagar P (2014) Strategies for protected cultivation for small and marginal farmers in India. Agriculture: towards a new paradigm of sustainability 158

Biondi A, Zappalà L, Desneux N, Aparo A, Siscaro G, Rapisarda C, Martin T, Garzia GT (2015) Potential toxicity of $\alpha$-cypermethrintreated nets on Tuta absoluta (Lepidoptera: Gelechiidae). J Econ Entomol 108(3):1191-1197

Boote KJ, Rybak MR, Scholberg JMS, Jones JW (2012) Improving the CROPGRO-tomato model for predicting growth and yield response to temperature. Hortscience 47(8):1038-1049

Boulard T, Haxaire R, Lamrani MA, Roy JC, Jaffrin A (1999) Characterization and modelling of the air fluxes induced by natural ventilation in a greenhouse. Journal of Agricultural Engineering Research 74(2):135-144. https://doi.org/10.1006/jaer.1999.0442

Boulard T, Raeppel C, Brun R, Lecompte F, Hayer F, Carmassi G, Gaillard G (2011) Environmental impact of greenhouse tomato production in France. Agron Sustain Dev 31(4):757-777. https://doi. org/10.1007/s13593-011-0031-3

Brévault T, Sylla S, Diatte M, Bernadas G, Diarra K (2014) Tuta absoluta Meyrick (Lepidoptera: Gelechiidae): a new threat to tomato production in Sub-Saharan Africa. African Entomology 22(2):441-444. https://doi.org/10.4001/003.022.0202

Briassoulis D, Hiskakis M, Babou E (2013) Technical specifications for mechanical recycling of agricultural plastic waste. Waste Management 33(6):1516-1530. https://doi.org/10.1016/j.wasman. 2013.03.004

Burney JA, Naylor RL, Postel SL (2013) The case for distributed irrigation as a development priority in sub-Saharan Africa. Proc Natl Acad Sci 110(31):12513-12517 
Carletto J, Martin T, Vanlerberghe-Masutti F, Brévault T (2010) Insecticide resistance traits differ among and within host races in Aphis gossypii. Pest Manag Sci 66(3):301-307

Castilla N (2013) Greenhouse technology and management. Cabi,

Chang J, Wu X, Wang Y, Meyerson LA, Gu B, Min Y, Xue H, Peng C, Ge Y (2013) Does growing vegetables in plastic greenhouses enhance regional ecosystem services beyond the food supply? Front Ecol Environ 11(1):43-49

Chatterjee R, Mahanta S, Pal P (2013) Adoption status and field level performance of different protected structures for vegetable production under changing scenario. Innovare J Agric Sci $11-13$

Cheema D, Singh N, Jindal S (2014) Comparative performance of tomato genotypes grown under net house and open field conditions. J Res 51(4):246-249

Chen Q, Zhang X, Zhang H, Christie P, Li X, Horlacher D, Liebig H-P (2004) Evaluation of current fertilizer practice and soil fertility in vegetable production in the Beijing region. Nutr Cycl Agroecosyst 69(1):51-58. https://doi.org/10.1023/B: FRES.0000025293.99199.ff

Chidege M, Al-zaidi S, Hassan N, Julie A, Kaaya E, Mrogoro S (2016) First record of tomato leaf miner Tuta absoluta (Meyrick)(Lepidoptera: Gelechiidae) in Tanzania. Agric Food Sec 5(1):17

Chikowo R, Zingore S, Snapp S, Johnston A (2014) Farm typologies, soil fertility variability and nutrient management in smallholder farming in Sub-Saharan Africa. Nutr Cycl Agroecosyst 100(1):1-18

Cissé I, Tandia AA, Fall ST (2003) Usage incontrôlé des pesticides en agriculture périurbaine: cas de la zone des Niayes au Sénégal. Cahiers Agric 12(3):181-186 (181)

Collier P, Dercon S (2014) African agriculture in 50 years: smallholders in a rapidly changing world? World Dev 63:92-101. https://doi.org/ 10.1016/j.worlddev.2013.10.001

De Bon H, Huat J, Parrot L, Sinzogan A, Martin T, Malézieux E, Vayssières J-F (2014) Pesticide risks from fruit and vegetable pest management by small farmers in sub-Saharan Africa. A review. Agron Sustain Dev 34(4):723-736

De Bon H, Parrot L, Moustier P (2010) Sustainable urban agriculture in developing countries. A review. Agron Sustain Dev 30(1):21-32

Deininger K, Byerlee D (2010) The rise of large-scale farms in landabundant developing countries: does it have a future. In: Conference Agriculture for Development-Revisited, University of California at Berkeley. pp 1-2

Deletre E, Schatz B, Bourguet D, Chandre F, Williams L, Ratnadass A, Martin T (2016) Prospects for repellent in pest control: current developments and future challenges. Chemoecology:1-16

Diop A, Diop YM, Thiaré DD, Cazier F, Sarr SO, Kasprowiak A, Landy D, Delattre F (2016) Monitoring survey of the use patterns and pesticide residues on vegetables in the Niayes zone, Senegal. Chemosphere 144:1715-1721. https://doi.org/10.1016/j. chemosphere.2015.10.058

Dorais M (2003) The use of supplemental lighting for vegetable crop production: light intensity, crop response, nutrition, crop management, cultural practices. In: Canadial Greenhouse Conference. pp 1-8

Du Plessis E, Workneh T, Laing M (2015) Greenhouse cooling systems and models for arid climate. In: Lichtfouse E (ed) Sustainable Agriculture Reviews: Volume 18. Springer International Publishing, Cham, pp 181-215. https://doi.org/10.1007/978-3-31921629-4 6

FAO (2009) How to Feed the World in 2050

FAO (2013) FAOSTAT. http://www.fao.org/faostat/en/\#data/OA. Accessed january 2017

Farias-Larios J, Orozco M, Guzman S, Perez J (1996) Effect of plastic mulch, floating Rowcovers, and microtunnels on insect populations and yield of muskmelon. Hortscience 31(4):677-677
Fatnassi H, Boulard T, Bouirden L (2003) Simulation of climatic conditions in full-scale greenhouse fitted with insect-proof screens. Agric For Meteorol 118(1-2):97-111. https://doi.org/10.1016/S01681923(03)00071-6

Gale F, Yang Z, Cook J (2013) China's vegetable exports peak as attention shifts to domestic market. USDA-ERS economic research report VGS-353-SA3

Gale HF (2013) Growth and evolution in China's agricultural support policies. USDA-ERS Economic Research Report (153)

Gilbert CL, Christiaensen L, Kaminski J (2016) Price seasonality in Africa: measurement and extent. World Bank Policy Research Working Paper (7539)

Gogo EO, Saidi M, Itulya FM, Martin T, Ngouajio M (2012) Microclimate modification using eco-friendly nets for high-quality tomato transplant production by small-scale farmers in East Africa. HortTechnology 22(3):292-298

Gogo EO, Saidi M, Itulya FM, Martin T, Ngouajio M (2014a) Ecofriendly nets and floating row covers reduce pest infestation and improve tomato (Solanum lycopersicum L.) yields for smallholder farmers in Kenya. Agronomy 4(1):1-12

Gogo EO, Saidi M, Ochieng JM, Martin T, Baird V, Ngouajio M (2014b) Microclimate modification and insect pest exclusion using Agronet improve pod yield and quality of French bean. Hortscience 49(10): 1298-1304

Gordon GG, Foshee WG, Reed ST, Brown JE, Vinson EL (2010) The effects of colored plastic mulches and row covers on the growth and yield of okra. HortTechnology 20(1):224-233

Gruda N, Tanny J (2014) Protected crops. In: Dixon RG, Aldous ED (eds) Horticulture: plants for people and places, Production horticulture, vol 1. Springer Netherlands, Dordrecht, pp 327-405. https://doi.org/ 10.1007/978-94-017-8578-5 10

Gu S (2009) The emergence and development of vegetable sector in China: an analysis from the sectoral innovation systems perspective. Forthcoming in the Journal Industry \& Innovation

Heuvelink E (2005) Tomatoes, vol 13. CABI

Holt J, Pavis C, Marquier M, Chancellor TCB, Urbino C, Boissot N (2008) Insect-screened cultivation to reduce the invasion of tomato crops by Bemisia tabaci: modelling the impact on virus disease and vector. Agric For Entomol 10(1):61-67. https://doi.org/10.1111/j. 1461-9563.2007.00356.x

Houndété TA, Kétoh GK, Hema OS, Brévault T, Glitho IA, Martin T (2010) Insecticide resistance in field populations of Bemisia tabaci (Hemiptera: Aleyrodidae) in West Africa. Pest Manag Sci 66(11): 1181-1185

Hu W, Zhang Y, Huang B, Teng Y (2017) Soil environmental quality in greenhouse vegetable production systems in eastern China: current status and management strategies. Chemosphere 170:183-195. https://doi.org/10.1016/j.chemosphere.2016.12.047

Jambeck JR, Geyer R, Wilcox C, Siegler TR, Perryman M, Andrady A, Narayan R, Law KL (2015) Plastic waste inputs from land into the ocean. Science 347(6223):768-771

Javier E (1990) Vegetable production training manual. Asian Vegetable Research and Development Centre, Taipei :63

Jensen MH, Malter AJ (1995) Protected agriculture: a global review, vol 253. World Bank Publications

Karungi J, Obua T, Kyamanywa S, Mortensen CN, Erbaugh M (2013) Seedling protection and field practices for management of insect vectors and viral diseases of hot pepper (Capsicum chinense Jacq.) in Uganda. Int J Pest Manag 59(2):103-110

Kaur S, Kaur S, Srinivasan R, Cheema D, Lal T, Ghai T, Chadha M (2010) Monitoring of major pests on cucumber, sweet pepper and tomato under net-house conditions in Punjab, India. Pest Manag Hortic Ecosyst 16(2):148-155

Keatinge J, Lin L-J, Ebert A, Chen W, Hughes JA, Luther G, Wang J-F, Ravishankar M (2014) Overcoming biotic and abiotic stresses in the 
Solanaceae through grafting: current status and future perspectives. Biol Agric Hortic 30(4):272-287

Khoshnevisan B, Rafiee S, Mousazadeh H (2013) Environmental impact assessment of open field and greenhouse strawberry production. Eur J Agron 50:29-37. https://doi.org/10.1016/j.eja.2013.05.003

Kiptoo J, Kasina M, Wanjala F, Kipyab P, Wasilwa L, Ngouajio M, Martin T (2015) Use of low cost pest exclusion nets can boost cabbage yield. East Afr Agric For J 81(2-4):112-119

Kittas C, Katsoulas N, Rigakis V, Bartzanas T, Kitta E (2012) Effects on microclimate, crop production and quality of a tomato crop grown under shade nets. J Hortic Sci Biotechnol 87(1):7-12

Kottek M, Grieser J, Beck C, Rudolf B, Rubel F (2006) World map of the Köppen-Geiger climate classification updated. Meteorol Z 15(3): 259-263

Kumar P, Poehling H-M (2006) Uv-blocking plastic films and nets influence vectors and virus transmission on greenhouse tomatoes in the humid tropics. Environ Entomol 35(4):1069-1082. https://doi.org/ 10.1603/0046-225x-35.4.1069

Lament WJ (1993) Plastic mulches for the production of vegetable crops. HortTechnology 3(1):35-39

Lang G, Miao B (2013) Food security for China's cities. Int Plan Stud 18(1):5-20. https://doi.org/10.1080/13563475.2013.750940

Lee J-M, Oda M (2010) Grafting of herbaceous vegetable and ornamental crops. In: Horticultural Reviews. John Wiley \& Sons, Inc., pp 61124. https://doi.org/10.1002/9780470650851.ch2

Licciardi S, Assogba-Komlan F, Sidick I, Chandre F, Hougard J-M, Martin T (2007) A temporary tunnel screen as an eco-friendly method for small-scale farmers to protect cabbage crops in Benin. Int J Trop Insect Sci 27(3-4):152-158

Liu Y, Chen J, Zhang X, Kamphuis B (2004) The vegetable industry in China: developments in policies, production, marketing and international trade

Louws FJ, Rivard CL, Kubota C (2010) Grafting fruiting vegetables to manage soilborne pathogens, foliar pathogens, arthropods and weeds. Sci Hortic 127(2):127-146. https://doi.org/10.1016/j. scienta.2010.09.023

Maertens M, Minten B, Swinnen J (2012) Modern food supply chains and development: evidence from horticulture export sectors in subSaharan Africa. Dev Policy Rev 30(4):473-497

Malherbe S, Marais D (2015) Economics, yield and ecology: a case study from the South African tomato industry. Outlook Agric 44(1):37-47

Martin T (2015) Eco-friendly nets to improve vegetable production and quality in sub-Saharan Africa. XXIX international horticultural congress on horticulture: sustaining lives, livelihoods and landscapes (IHC2014) 1105:221-228

Martin T, Assogba-Komlan F, Houndete T, Hougard J-M, Chandre F (2006) Efficacy of mosquito netting for sustainable small holders' cabbage production in Africa. J Econ Entomol 99(2):450-454

Martin T, Assogba-Komlan F, Sidick I, Ahle V, Chandre F (2010) An acaricide-treated net to control phytophagous mites. Crop Protection 29(5):470-475. https://doi.org/10.1016/j.cropro.2009.11.004

Martin T, Chandre F, Ochou O, Vaissayre M, Fournier D (2002) Pyrethroid resistance mechanisms in the cotton bollworm Helicoverpa armigera (Lepidoptera: Noctuidae) from West Africa. Pestic Biochem Physiol 74(1):17-26

Martin T, Gogo E, Saidi M, Kamal A, Deletre E, Bonafos R, Simon S, Ngouajio M (2014a) Repellent effect of an alphacypermethrin treated net against the whitefly Bemisia tabaci Gennadius. J Econ Entomol 107:684-690

Martin T, Palix R, Kamal A, Delétré E, Bonafos R, Simon S, Ngouajio M (2013) A repellent net as a new technology to protect cabbage crops. J Econ Entomol 106(4):1699-1706

Martin T, Saidi M, Assogba Komlan F, Simon S, Kasina M, Vidogbena F, Parrot L, Adegbidi A, Wasilwa L, Subramanian S, Baird V, Ngouajio M (2014b) Eco-friendly nets to improve vegetable production and quality in sub-Saharan Africa. Paper presented at the
XXIX international horticultural congress on horticulture: sustaining lives, livelihoods and landscapes (IHC2014): international symposia on innovative plant protection in horticulture, biosecurity, quarantine pests, and market access, Brisbane

Martínez-Blanco J, Muñoz P, Antón A, Rieradevall J (2011) Assessment of tomato Mediterranean production in open-field and standard multi-tunnel greenhouse, with compost or mineral fertilizers, from an agricultural and environmental standpoint. J Clean Prod 19(910):985-997. https://doi.org/10.1016/j.jclepro.2010.11.018

Midmore D, Roan Y, Wu M (1997) Management practices to improve lowland subtropical summer tomato production: yields, economic returns and risk. Exp Agric 33(02):125-137

Muleke EM, Saidi M, Itulya FM, Martin T, Ngouajio M (2012) The assessment of the use of eco-friendly nets to ensure sustainable cabbage seedling production in Africa. Agronomy 3(1):1-12

Muleke EM, Saidi M, Itulya FM, Martin T, Ngouajio M (2014) Enhancing cabbage (brassica oleraceae Var capitata) yields and quality through microclimate modification and physiological improvement using agronet covers. Sustain Agric Res 3(2):24

Muñoz P, Antón A, Nuñez M, Paranjpe A, Ariño J, Castells X, Montero J, Rieradevall J (2007) Comparing the environmental impacts of greenhouse versus open-field tomato production in the Mediterranean region. In: International Symposium on High Technology for Greenhouse System Management: Greensys 801, 2007. pp 1591-1596

Mutengwe MT, Aneck-Hahn NH, Korsten L, Van Zijl MC, De Jager C (2016) Pesticide residues and estrogenic activity in fruit and vegetables sampled from major fresh produce markets in South Africa. Food Addit Contam Part A 33(1):95-104

Mutisya S, Saidi M, Opiyo A, Ngouajio M, Martin T (2016) Synergistic effects of Agronet covers and companion cropping on reducing whitefly infestation and improving yield of open field-grown tomatoes. Agronomy 6(3):42

Nisen A, Grafiadellis M, Jiménez R, La Malfa G, Martínez-García P, Monteiro A, Verlodt H, Od V, Cv Z, Denis J (1988) Cultures protégées en climat méditerranéen. Organisation des Nations unies pour l'alimentation et l'agriculture, Rome

Ntsoane LLM, Soundy P, Jifon J, Sivakumar D (2016) Variety-specific responses of lettuce grown under the different-coloured shade nets on phytochemical quality after postharvest storage. J Hortic Sci Biotechnol 91(5):520-528. https://doi.org/10.1080/14620316. 2016.1178080

Omoro PA, Shitandi A, Aming'a NN, Basweti E (2015) Assessing the extension staff farm visits frequency effect on greenhouse technology performance in small scale farms in Gusii highlands, Kenya. Open Access Library J 2(2):1-10. https://doi.org/10.4236/oalib. 1101135

Orsini F, Kahane R, Nono-Womdim R, Gianquinto G (2013) Urban agriculture in the developing world: a review. Agron Sustain Dev 33(4):695-720. https://doi.org/10.1007/s13593-013-0143-z

Page G, Ridoutt B, Bellotti B (2012) Carbon and water footprint tradeoffs in fresh tomato production. J Clean Prod 32:219-226. https://doi. org/10.1016/j.Jclepro.2012.03.036

Paris H, Janick J (2008) What the Roman emperor Tiberius grew in his greenhouses. In: Cucurbitaceae 2008, Proceedings of the IXth EUCARPIA Meeting on Genetics and Breeding of Cucurbitaceae. pp 33-42

Parrot L, Assogba Komlan F, Vidogbena F, Adegbidi A, Baird V, Martin T, Simon S, Saidi M, Kasina M, Wasilwa LA (2014) Eco-friendly nets to improve vegetable production and quality in sub-Saharan Africa. In: XXIX International Horticultural Congress on Horticulture: Sustaining Lives, Livelihoods and Landscapes (IHC2014): 1105. pp 221-228

Paul ND, Gwynn-Jones D (2003) Ecological roles of solar UV radiation: towards an integrated approach. Trends Ecol Evol 18(1):48-55. https://doi.org/10.1016/S0169-5347(02)00014-9 
Payen S, Basset-Mens C, Perret S (2015) LCA of local and imported tomato: an energy and water trade-off. J Clean Prod 87:139-148

Peet M, Welles G (2005) Greenhouse tomato production. Crop Prod Scie Hortic 13:257

Perrin A, Basset-Mens C, Gabrielle B (2014) Life cycle assessment of vegetable products: a review focusing on cropping systems diversity and the estimation of field emissions. Int J Life Cycle Assess 19(6): $1247-1263$

Perrin A, Basset-Mens C, Huat J, Gabrielle B (2017) The variability of field emissions is critical to assessing the environmental impacts of vegetables: a Benin case-study. J Clean Prod 153:104-113. https:// doi.org/10.1016/j.jclepro.2017.03.159

Perrin A, Basset-Mens C, Huat J, Yehouessi W (2015) High environmental risk and low yield of urban tomato gardens in Benin. Agron Sustain Dev 35(1):305-315. https://doi.org/10. 1007/s13593-014-0241-6

PlasticsEurope (2015) An analysis of European plastics production, Demand and Waste Data

Ponce P, Molina A, Cepeda P, Lugo E, MacCleery B (2014) Greenhouse design and control. CRC Press

Raviv M, Antignus Y (2004) UV radiation effects on pathogens and insect pests of greenhouse-grown crops. Photochem Photobiol 79(3):219-226

Reddy PP (2015) Sustainable crop protection under protected cultivation. Springer,

Reuveni R, Raviv M (1997) Control of downy mildew in greenhousegrown cucumbers using blue photoselective polyethylene sheets. Plant Dis 81(9):999-1004

Romero-Gámez M, Antón A, Soriano T, Suárez-Rey EM, Castilla N (2009) Environmental impact of greenbean cultivation: comparison of screen greenhouses vs. open field. J Food Agric Environ 7(3-4): $132-138$

Rubeiz IG, Freiwat MM (1995) Rowcover and black plastic mulch effects on tomato production. Biol Agric Hortic 12(2):113-118. https://doi. org/10.1080/01448765.1995.9754731

Russo G, Scarascia Mugnozza G (2004) LCA methodology applied to various typology of greenhouses. In: International Conference on Sustainable Greenhouse Systems-Greensys 2004 691. pp 837-844

Saidi M, Gogo EO, Itulya FM, Martin T, Ngouajio M (2013) Microclimate modification using eco-friendly nets and floating row covers improves tomato (Lycopersicon esculentum) yield and quality for small holder farmers in East Africa. Agric Sci 4(11):577

Scarascia-Mugnozza G, Sica C, Russo G (2012) Plastic materials in European agriculture: actual use and perspectives. J Agric Eng 42(3):15-28

Schwarz D, Rouphael Y, Colla G, Venema JH (2010) Grafting as a tool to improve tolerance of vegetables to abiotic stresses: thermal stress, water stress and organic pollutants. Sci Hortic 127(2):162-171

Selahle KM, Sivakumar D, Jifon J, Soundy P (2015) Postharvest responses of red and yellow sweet peppers grown under photoselective nets. Food Chem 173:951-956. https://doi.org/10.1016/j. foodchem.2014.10.034

Sethi VP (2009) On the selection of shape and orientation of a greenhouse: thermal modeling and experimental validation. Solar Energy 83(1):21-38. https://doi.org/10.1016/j.solener.2008.05.018

Sharma R, Bansal PP (2016) Use of different forms of waste plastic in concrete - a review. J Clean Prod 112(part 1):473-482. https://doi. org/10.1016/j.jclepro.2015.08.042

Simon S, Komlan F, Adjaïto L, Mensah A, Coffi HK, Ngouajio M, Martin T (2014) Efficacy of insect nets for cabbage production and pest management depending on the net removal frequency and microclimate. Int J Pest Manag 60(3):208-216. https://doi.org/10. 1080/09670874.2014.956844

Singh B, Kumar M, Sirohi N (2005) Protected cultivation of cucurbits under low-cost protected structures: a sustainable technology for peri-urban areas of Northern India. In: III International Symposium on Cucurbits 731. pp 267-272

Singh D, Basu C, Meinhardt-Wollweber M, Roth B (2015) LEDs for energy efficient greenhouse lighting. Renew Sust Energ Rev 49: 139-147. https://doi.org/10.1016/j.rser.2015.04.117

Steinmetz Z, Wollmann C, Schaefer M, Buchmann C, David J, Tröger J, Muñoz K, Frör O, Schaumann GE (2016) Plastic mulching in agriculture. Trading short-term agronomic benefits for long-term soil degradation? Sci Total Environ 550:690-705. https://doi.org/10. 1016/j.scitotenv.2016.01.153

Talekar N, Su F, Lin M (2003) How to grow safer leafy vegetables in nethouses and net tunnels. International Cooperator's Guide, Asian Vegetable Research and Development Center Publication :03-558

Tegen H, Dessalegn Y, Mohammed W (2016) Influence of mulching and varieties on growth and yield of tomato under polyhouse. J Hortic Forestry $8(1): 1-11$

Tinyane PP, Sivakumar D, Soundy P (2013) Influence of photo-selective netting on fruit quality parameters and bioactive compounds in selected tomato cultivars. Sci Hortic 161:340-349. https://doi.org/10. 1016/j.scienta.2013.06.024

Tonnang HE, Mohamed SF, Khamis F, Ekesi S (2015) Identification and risk assessment for worldwide invasion and spread of Tuta absoluta with a focus on sub-Saharan Africa: implications for phytosanitary measures and management. PLoS One 10(8):e0135283

Torrellas M, Antón A, Ruijs M, García Victoria N, Stanghellini C, Montero JI (2012) Environmental and economic assessment of protected crops in four European scenarios. J Clean Prod 28:4555. https://doi.org/10.1016/j.jclepro.2011.11.012

Traoré SK, Mamadou K, Dembele A, Lafrance P, Mazelliert P, Houenou P (2006) Contamination de l'eau souterraine par les pesticides en régions agricoles en Côte d'Ivoire (centre, sud et sud ouest). J Afr Sci Environ 1(1):1-9

Vaissiere BE, Froissart R (1996) Pollination of cantaloupes under spun bonded row cover by honey bees (Hymenoptera: Apidae) in West Africa. J Econ Entomol 89(5):1213-1222

Van Lenteren JC (2000) A greenhouse without pesticides: fact or fantasy? Crop Protect 19(6):375-384. https://doi.org/10.1016/S02612194(00)00038-7

Vidogbéna F, Adégbidi A, Assogba-Komlan F, Martin T, Ngouajio M, Simon S, Tossou R, Parrot L (2015a) Cost: benefit analysis of insect net use in cabbage in real farming conditions among smallholder farmers in Benin. Crop Prot 78:164-171

Vidogbéna F, Adégbidi A, Tossou R, Assogba-Komlan F, Ngouajio M, Martin T, Simon S, Parrot L, Zander KK (2015b) Control of vegetable pests in Benin - farmers' preferences for eco-friendly nets as an alternative to insecticides. J Environ Manag 147:95-107. https:// doi.org/10.1016/j.jenvman.2014.09.010

Von Zabeltitz C (2011) Cladding Material. In: Integrated Greenhouse Systems for Mild Climates. Springer, pp 145-167

Wachira JM, Mshenga PM, Saidi M (2014) Comparison of the profitability of small-scale greenhouse and open-field tomato production systems in Nakuru-North District, Kenya. Asian J Agric Sci 6(2):54-61

Walpole M, Smith J, Rosser A, Brown C, Schulte-Herbruggen B, Booth H, Sassen M, Mapendembe A, Fancourt M, Bieri M (2013) Smallholders, food security, and the environment. International Fund for Agricultural Development (IFAD) and United Nations Environment Programme (UNEP). Available online at http:// www.unep.org/pdf/SmallholderReport_WEB.pdf.

Weintraub PG (2009) Physical control: an important tool in pest management programs. In: Biorational Control of Arthropod Pests. Springer, pp 317-324

Wiggins S (2009) Can the smallholder model deliver poverty reduction and food security. Paper presented at the How to Feed the World in 2050, Rome,

Wilson C, Tisdell C (2001) Why farmers continue to use pesticides despite environmental, health and sustainability costs. Ecological 
Economics 39 (3):449-462. https://doi.org/10.1016/S09218009(01)00238-5

Yang N-W, Zang L-S, Wang S, Guo J-Y, Xu H-X, Zhang F, Wan F-H (2014) Biological pest management by predators and parasitoids in the greenhouse vegetables in China. Biol Control 68:92-102. https://doi.org/10.1016/j.biocontrol.2013.06.012

Yehouenou AEP, Azehoun J, Aléodjrodo P, van Straalen N, van Hattum B, van Gestel CM (2013) Health risks associated with pesticide residues in sediments, fish, and plants from the Ouémé Valley in the Republic of Bénin. Arch Environ Contam Toxicol 65(2):260 265. https://doi.org/10.1007/s00244-013-9895-3

Yi-Zhang C, Zhangen Z (2000) Shanghai: trends towards specialised and capital-intensive urban agriculture. Growing cities, growing food, urban agriculture on the policy agenda:467-476 